\title{
Lecythidaceae Poit. in the Tupé Sustainable Development Reserve, Manaus, Brazil ${ }^{1}$
}

\author{
LUISA BRASIL VIANA MATTA ${ }^{2,4}$ and VERIDIANA VIZONI SCUDELLER ${ }^{3}$
}

(received: November 30, 2011; accepted: April 12, 2012)

\begin{abstract}
Lecythidaceae Poit. in the Tupé Sustainable Development Reserve, Manaus, Brazil). Lecythidaceae is the family of the Brazil nut, and comprises about 300 species belonging to 17 genera with pantropical distributions. One hundred and twenty-two species belonging to nine genera are distributed throughout Brazil, demonstrating its greatest diversity in the Amazon rainforest where Lecythidaceae is also one of the most abundant families. It is usually difficult to collect fertile material from these trees because of their canopy heights, and species determinations using sterile material can be complex because of their morphological similarities. There have been relatively few studies of this family even though it is one of the most important groups in the Amazon region, and a detailed taxonomic treatment of the species of Lecythidaceae in the Tupé Sustainable Development Reserve was therefore the goal of the present work. Ten species were found, Allantoma lineata (Mart. ex O.Berg) Miers, Bertholletia excelsa Bonpl., Couratari tenuicarpa A.C.Sm., Lecythis poiteaui O.Berg; and six species of Eschweilera, the richest genus. The descriptions and identification keys of the species used 56 characters. The main reproductive characters useful for distinguishing the species were the pubescence of the inflorescence rachis, pedicel length and trichomes presence, floral symmetry, hood type, filament shape, stigma shape, fruit shape and size, and aril type. The most diagnostic vegetative characters were the type and color of the outer bark, inner bark color, midrib prominence, and petiole shape and pubescence.
\end{abstract}

Key words - Amazon, external morphology, Lecythidoideae, Reserva do Tupé, taxonomy

\section{INTRODUCTION}

The Lecythidaceae have a pantropical distribution, and comprises approximately 17 genera and 300 species. The greatest diversity of this group occurs in the neotropics especially in the Amazon region and the Guianas (Mori \& Prance 1990). These plants occur in many environments but are most abundant in non-flooding primary forests (Mori \& Prance 1990) and are therefore considered indicators for preserved or little-disturbed areas (Mori et al. 2007).

Among the principal characteristics used to recognize the neotropical Lecythidaceae is their arboreal habit, simple alternate leaves, and the presence of cortical bundles in the bark that produce fibers (envira) - a distinct vegetative characteristic that differentiates this taxon from most other groups of trees. The flowers can be actinomorphic or zygomorphic, with the zygomorphic flowers having an extension on one side of the stamen ring called a ligule, which terminates in a hood (exclusive to neotropical Lecythidaceae); they

\footnotetext{
1. Part of the Master's dissertation of the first author, Programa de Pós-Graduação em Botânica, Instituto Nacional de Pesquisas da Amazônia, Manaus, AM, Brazil.

2. Instituto Nacional de Pesquisas da Amazônia, Av. André Araújo, 2936, Aleixo, 69060-001 Manaus, AM, Brazil.

3. Universidade Federal do Amazonas, Departamento de Botânica, Av. General Rodrigo Octávio Jordão Ramos, 3000, Campus Universitário, Coroado I, Manaus, AM, Brazil.

4. Corresponding author: luisabvm@yahoo.com.br
}

have numerous stamens; the ovary is frequently inferior and the ovules bitegumented, with axial placentation; the fruit of most of the genera are dehiscente and of the pyxidium type (also exclusive to this family) (Prance \& Mori 2004).

Lecythidaceae is included within the order Ericales, and in spite of the fact that its position within the clade is not well-defined, is considered monophyletic (Anderberg et al. 2002). The complete phylogeny of the family has not yet been fully resolved, however, and although the genera with actinomorphic flowers form a monophyletic group there are still divergences in terms of its sub-families. The APG III (2009) considers the family as comprising five subfamilies: Napoleonaeoideae, Scytopetaloideae, Foetidioideae, Planchonoideae, and Lecythidoideae. Mori et al. (2007), however, consider the family to be represented by only three subfamilies (Foetidioideae, Planchonoideae, and Lecythidoideae), with Napoleonaceae and Scytopetalaceae being considered separate families from the Lecythidaceae. In spite of the fact that these three subfamilies are monophyletic, the relationships of their component taxa have not been fully resolved, especially among the Lecythidoideae.

The subfamily Lecythidoideae only occurs within the neotropics, and comprises 214 species grouped within 10 genera; it is widely distributed within Brazil, with 122 species belonging to nine genera, of which 54 are endemic. The subfamily is more diverse in the Guiana shield and in the Brazilian Amazon forest (with 
95 endemic species); 11 endemic species are found in the Atlantic Forest biome (Smith et al. 2010).

In spite of the ecological importance of Lecythidaceae and its diversity within the Amazon forest and the publication of numerous studies by Scott Mori (the Lecythidaceae pages - http://sweetgum. nybg.org/lp/index.php), there is still the need for more taxonomic and descriptive studies of this family as we do not yet have complete information about all species. The principal monographs concerning the Lecythidaceae were published in the Flora Neotropica (Prance \& Mori 1979, Mori \& Prance 1990) and included keys for the identification of each genus and detailed descriptions of each of the 197 species known at the time, together with maps of their distributions. Seventeen new neotropical species of Lecythidaceae have been described since that time, with the two most recent members being described in 2010 (Grias purpuripetala S.A. Mori, J.D. García-González, S. Angel \& C. Alvarado, and Grias theobromicarpa Cornejo \& S.A. Mori).

Publications such as the Flora of Costa Rica (Mori 2007), the Flora of Venezuela (Mori \& Prance 1999), and the Flora of the Guianas (Mori \& Prance 1993) have provided identification keys and descriptions for the Lecythidaceae. The work undertaken in French Guiana stands out as being one of the most complete examinations of the family, and included studies of the taxonomy, anatomy, pollination, and ecology (Mori et al. 1987). The online monograph Lecythidaceae Pages (Mori et al. 2010) has been available on the internet since 2006, and provides the most up-to-date descriptions and information about the known species of neotropical Lecythidaceae.

In spite of the availability of these important works on the taxonomy of the Lecythidaceae many difficulties are still encountered in identifying specimens in the field as well as in herbaria resulting in a significant level of erroneous determinations particularly those of nonspecialists - and principally because the most abundant species are vegetatively very similar. Approximately $20 \%$ of the specimens in the herbarium at the Amazonian National Research Institute (INPA) have been identified only to the genus level. The genus Eschweilera is probably the most serious case, with $30.8 \%$ of its 2087 specimens not having been indentified to species level (source: INPA Herbarium - http://brahms.inpa.gov.br/ bol/). This high percentage is principally due to the large number of sterile collections.

Studies of the taxonomy of this family in the Brazilian Amazon are still insufficient. The first studies concerning the taxonomy of this group were made by
Mori \& Lepsch-Cunha (1995) in Reserve 1501 of the Biological Dynamics of Forest Fragments Project (PDBFF), with the publication of identification keys for each genus and detailed descriptions of each species based on the external morphology of their vegetative and productive organs; this study registered 39 species belonging to eight genera, including three new species. Another study published by Hopkins \& Mori (1999) in the Flora of the Ducke Reserve recorded the same eight genera and 39 species but included seven other species occurring in the reserve. Different from the publication described above, this work used only vegetative characters in the identification guide.

In the Tupé Sustainable Development Reserve (Tupé SDR) only two species of Lecythidaceae [Eschweilera apiculata (Miers) A.C.Sm. and Eschweilera bracteosa Poepp. ex O.Berg) Miers] had previously been identified in terra-firme (upland) areas (Scudeller et al. 2009) and two other species (Eschweilera tenuifolia (O.Berg) Miers and Couratari tenuicarpa A.C.Sm.) in igapó (seasonally flooded) areas (Scudeller \& Souza 2009).

The scarcity of detailed floristic inventories that include taxonomic studies has made it difficult to map the geographical distributions of many species, identify their intra-specific variability, and even to discover new species. This information is of enormous importance in determining the phylogeny of the family - which has not yet been fully resolved. Local floras with detailed keys and descriptions contribute greatly to our phylogenetic knowledge of plant groups, and the present study presents identification keys and detailed and standardized descriptions of the Lecythidaceae species encountered in the Tupé SDR (with special emphasis on vegetative characters) with the goal of facilitating species determinations and increasing our knowledge about this family.

\section{MATERIAL AND METHODS}

Collections were made in the Tupé Sustainable Development Reserve (Tupé SDR), located on the left bank of the Negro River, to the west of Manaus, Amazonas State, Brazil. Two types of forest vegetation predominate in the reserve: Dense Ombrophilous Forests (terra-firme forest) and Alluvial Dense Ombrophilous Forests (igapó forest), the latter being encountered in areas near Tupé Lake (Hamaguchi 2009). Monthly excursions were made to the reserve between January/2010 and March/2011. In addition to the material collected in this period, specimens that had been collected during previous surveys in the reserve were also considered (Scudeller \& Souza 2009, Scudeller et al. 2009). Specimens that were used in preparing the identification keys were documented in the field with written descriptions and with 
photographs (using a Nikon Coolpix L20 digital camera). The collected material was pressed and stored and some of the flowers were conserved in $70 \%$ alcohol for posterior laboratory studies.

Identifications of the collected specimens were made using identification keys (Prance \& Mori 1979, Mori \& Prance 1990, Mori \& Lepsch-Cunha 1995, Hopkins \& Mori 1999), by consulting the site http://sweetgum.nybg.org/lp/ index.php, by comparisons with material deposited in the INPA herbarium, and with the aid of Dr. Scott A. Mori, a known specialist in the field. A total of 56 morphological characters (20 vegetative and 36 reproductive) were selected to compose the descriptions and the identification key. The specimens were carefully examined using a stereomicroscope and their dimensions determined using a digital caliper or a millimeter rule and photographed using a Leica EZ4D stereomicroscope with an integrated digital camera. In the absence of flowers or fruit on the mature material collected in the Tupé SDR, information regarding these organs was complemented with the information on INPA herbarium labels of existing material.

The nomenclature adopted to describe the types and colors of the external and inner bark followed Mori \& Prance (1990), Mori \& Lepsch-Cunha (1995), and Hopkins \& Mori (1999); the terminology used to describe the architecture, shapes and sizes of the leaves, the shape of the apex and base, and the leaf margins followed Ellis et al. (2009); the general morphological descriptions followed Radford et al. (1974). The terminology adopted for describing the flowers and fruit followed Prance \& Mori (1979).

The characters and their variations were edited in the DELTA (Description Language for Taxonomy) program, which is a versatile compilation of computer programs specifically developed for applications in Biological Systematics (Cavalcanti \& Santos-Silva 2009). The data entered into the DELTA program was codified, and standardized descriptions of the species were generated and elaborated into identification keys - one key utilizing both vegetative and reproductive characters and the other based on vegetative characters and the habitats of the plants. These species descriptions were largely based on the characteristics of the plants collected in the study area; only when it was not possible to observe a given characteristic the descriptions were complemented with observations made in other areas.

\section{RESULTS AND DISCUSSION}

Ten species belonging to five genera of Lecythidaceae were found in the Tupé SDR. The richest genus was
Eschweilera, with six species, while the other genera (Allantoma, Bertholletia, Couratari, and Lecythis) were represented by only a single species each. All of the species collected had arboreal habits; three occurred in seasonally flooded (igapó) areas while the others were exclusively upland (terra-firme) species. Previous to the current survey, only two species of Lecythidaceae were known from the upland forests and two from seasonally flooded sites in the Tupé SDR. After detailed examinations of the two upland species the previous identifications were determined to be incorrect. Eschweilera apiculata was actually E. tessmannii and the individuals identified as $E$. bracteosa in fact belonged to two distinct species, E. coriacea and E. truncata. The species from the seasonally flooded sites had been correctly identified.

Lecythidoideae (Lecythidaceae) Nied. in Engler \& Prantl, Nat. Pflanzenfam. 3(7): 34-41. 1892

Trees small to very large (emergent). Leaves simples, alternate, camptodromous, margins usually entire, sometimes crenulate to serrate; very large and grouped on the terminal portion of the branch in Couroupita, Grias, and Gustavia; smaller and not grouped in the other genera. Inflorescence terminal, axillary or caulinary; raceme simple or a spike, rarely fasciculate. Flowers actinomorphic or zygomorphic; calyx entire or with 2-6 lobes; petals 4-6(-8) or rarely 12 or 18 ; stamens numerous, forming a stamen tube in Allantoma, Grias, and Gustavia; the stamen ring is slightly expanded on one of its sides in Cariniana, and markedly expanded and forming a laminated ligule with an apical hood in the other genera, the appendices associated with the hood with or without anthers, pollen fertile in all of the stamens or some stamens with fertile pollen and others with sterile pollen; ovary normally 2-4(-6) locular, with 2-115 anatropous ovules per locule, placentation axial or, less frequently, basal or apical, ovules pendulous or erect. Fruits indehiscent of the fleshy berry type (Grias and Gustavia), with a thin and woody exocarp (Couroupita), or dehiscent by way of a circumscissile operculum (pyxidium) in the other genera. Seeds alate (Cariniana and Couratari); funicle well-developed and twisted (Gustavia); aril present or absent, may be lateral, basal, or cover the entire seed.

Analytical key for identifying the Lecythidaceae in the Tupé SDR

1. Habitat upland (terra-firme) forest

2. Hood thick at apex with appendages turned inwards, fruit rounded; 2 sepals 2. Bertholletia excelsa

2. Hood flat or forming a double spiral; fruit subglobose or turbinate; seeds with basal aril; 6 sepals 
3. Hood flat; fruit subglobose; leaves large $(11.5-17.5 \mathrm{~cm}$ long) with adaxial face shiny and crenate margins; outer bark with superficial vertical fissures; inner bark brightyellow

10. Lecythis poiteaui

3. Hood forming a double spiral; fruit turbinate; leaves small $(6-11 \mathrm{~cm}$ long) with adaxial face slightly shiny and margins smooth; outer bark smooth; inner bark reddish-yellow

4. Eschweilera amazonica

4. Outer bark of stem dark-brown, with sloughing; inner bark yellow; fruit subglobose

5. Stigma erect, style not differentiated from the cupule of the ovary; rachis of the inflorescence and pedicel with trichomes; outer bark frequently with lenticels, abaxial face of the midrib with trichomes; midrib not prominent on adaxial face

6. Eschweilera coriacea

5. Stigma oblique, style differentiated from the cupule of the ovary; rachis of the inflorescence and pedicel glabrous; outer bark without lenticels, abaxial face of the midrib glabrous; midrib salient on adaxial face 9. Eschweilera truncata

4. Outer bark of stem gray or grayish-brown, smooth or with vertical plaques; inner bark red; fruit obconical

6. Outer bark of the stem gray, smooth; fruit with caducous calyx; sepals ovate, petals pink

8. Eschweilera tessmannii

6. External stem bark grayish-brown, with vertical plaques; fruit with persistent calyx; sepals triangular; petals white

5. Eschweilera atropetiolata

1. Habitat seasonally flooded (igapó)

7. Flowers actinomorphic; inner bark reddish-yellow; rachis of the inflorescence and pedicel glabrous 1. Allantoma lineata

7. Flowers zygomorphic; inner bark dark-yellow; rachis of the inflorescence and pedicel with trichomes

8. Hood with double spiral; stigma umbonate, style poorly differentiated from the cupule of the ovary; ovary bilocular; seeds without aril

7. Eschweilera tenuifolia

8. Hood with internal double spiral and a extra external flap; stigma erect, style not differentiated from the cupule of the ovary; ovary trilocular; aril dry alate, covering the entire seed

3. Couratari tenuicarpa

Analytical key of the Lecythidaceae of the Tupé SDR based on vegetative and habitat characters

1. Habitat upland (terra-firme) forest

2. Petiole with trichomes

3. Petiole with concave adaxial face

2. Bertholletia excelsa

3. Petiole with flat adaxial face

4. Outer bark of the stem dark-brown, inner bark yellow

5. Stems with lenticels and large buttress roots; midrib with trichomes, salient on abaxial face, intruse on adaxial face, abundant reddish spots on the abaxial face

6. Eschweilera coriacea

5. Stem without lenticels or large buttress roots; midrib glabrous, prominent on both faces, reddish spots sparse or absent on abaxial face 9. Eschweilera truncata

4. Outer bark of stem gray or grayish brown; inner bark red

6. Outer bark smooth; midrib glabrous, abaxial face of leaf dull and with salient tertiary veins

8. Eschweilera tessmannii

6. Outer bark with thin and narrow plaques; midrib with trichomes; abaxial face of the leaf whitish and with impressed tertiary veins

5. Eschweilera atropetiolata

2. Petiole glabrous

7. Inner bark bright-yellow; outer bark with superficial vertical fissures and lenticels; leaves with crenulate margins 10. Lecythis poiteaui

7. Inner bark reddish-yellow; outer bark, smooth, without lenticels; with smooth margins 
1. Habitat seasonally flooded (igapó)

8. Secondary veins eucamptodromous; inner bark reddish-yellow 1. Allantoma lineata

8. Secondary veins brochidodromous; inner bark dark-yellow

9. Outer bark gray with superficial vertical furrows and lenticels; trunk with large buttress roots 3. Couratari tenuicarpa

9. Outer bark grayish-brown, fissured, without lenticels; base of trunk cylindrical 7. Eschweilera tenuifolia

Allantoma Miers, Trans. Linn. Soc. London 30: 291. 1874.

The genus characteristically comprises upper canopy and emergent trees; medium to large sized leaves (6-30 cm long), glabrous, tertiary venation percurrent; inflorescence racemose or paniculate; flowers with actinomorphic androecium; 5 sepals and 5 petals; androecium forming a stamen tube with stamens along the margins or spread on the internal surface of the tube; fruit of pyxidium type, cylindrical; seed unilaterally alate.

Eight species are distributed through the western Amazon (except $A$. lineata); from the headwaters of the Negro River to the mouth of the Amazon River in Brazil and on the eastern side of the Amazon River (except $A$. lineata); not found in the Guianas (Mori et al. 2010). Only a single species was found in the Tupé SDR.

1. Allantoma lineata (Mart. ex O.Berg.) Miers, Trans. Linn. Soc. London 30 (2): 297. 1874.

Couratari lineata Mart. ex O.Berg., Fl. bras. 14(1): 508, t. 7, 77. 1858.

Figures 1-10

Trees $18 \mathrm{~m}$ tall. Trunk and base cylindrical; outer bark brown, smooth, with little sloughing, lenticels in vertical rows; inner bark reddish-yellow. Leaf with both faces dull; petiole glabrous, flat convex, 9.0-17.5 mm long; leaf blade elliptical or oblong, $12.5-23.5 \times 4.5-10.0 \mathrm{~cm}$, glabrous, coriaceous; base rounded; margins entire; apex acuminate; venation eucamptodromous; midrib salient on both faces. Inflorescence terminal, racemose or principal rachis with one order of branching, glabrous, 7.0-9.5 cm long; pedicel glabrous, $1.5-2.0 \mathrm{~mm}$ long. Flowers actinomorphic; calyx with 5-6 sepals, indistinct, 2.6-3.3 $\times 2.5-3.0 \mathrm{~mm}$, united, green; petals 5, oblong or ovate, with apex turned inward, 11.7-16.0 × 4.0-4.7 mm, valvate, white; stamen tube with ca. 50 stamens, filaments adnate to the tube, $0.9-1.5 \mathrm{~mm}$ long, anthers rimose, 0.7-1.2 mm long; ovary inferior, 4 locular, many ovules per locule, placentation axial, stigma short, differentiated from the cupule of the ovary, $1.0 \mathrm{~mm}$ long. Fruit dehiscent, cylindrical, 7.0-11.0 × 4.0-5.5 cm, calyx not expanded during fruit development, operculum with columella. Seeds 4.5-5.5 $\times 0.8-1.0 \mathrm{~cm}$, aril vestigial alate in immature seeds, absent in mature seeds.

This species is easily recognized in the field by its smooth bark with many vertically oriented lenticels and eucamptodromous leaves with salient primary and secondary venation. According to Mori \& Lepsch-Cunha (1995), this species is characterized by its cylindrical trunk; leaf blades oblong and with percurrent tertiary veins that are indistinct and very close to each other; flower buds oblong; petal color varies from white to yellow, apices hook-shaped and turned inwards towards the interior of the corolla; androecium actinomorphic with stamens distributed throughout the stamen tube at differing heights; fruits long and cylindrical; seeds with basal aril. Similar to Allantoma decandra (Ducke) S.A. Mori, Ya Y.Huang \& Prance as the leaves of both species are eucamptodromous and their tertiary veins are opposite percurrent. The species are distinguishable as A. lineata has a longer stamen tube (up to $10 \mathrm{~mm}$ long) with 8-10 stamens in vertical rows and cylindrical fruit with smooth to rugose surfaces, while $A$. decandra has a short stamen tube with only a single row of stamens inserted near the apex, and its fruit have very visible vertical lines. Among the species studied, only A. lineata has actinomorphic flowers and adnate filaments forming a stamen tube whose anthers are arranged at different heights along the tube. No pollination studies have yet been undertaken with this species, although Prance \& Mori (1979) suggested that it is pollinated by small insects because of its very small flowers. Seed dispersal in A. lineata is by hydrochory, as the seed testa is rough, with vestigial wings (different from the other species of the genus, which have seeds with lateral wings); the seeds of $A$. lineata float due to their high oil content (Ducke 1948) and they can remain viable for up to three months (Prance \& Mori 1979).

This species was collected in the Tupe SDR with fruit in February, but the structures were very old and did not still contain any seeds; this species was collected in a seasonally flooded forest (igapó). Prance \& Mori (1979) reported that $A$. lineata could be found flowering throughout the year but that the most abundant flowering 

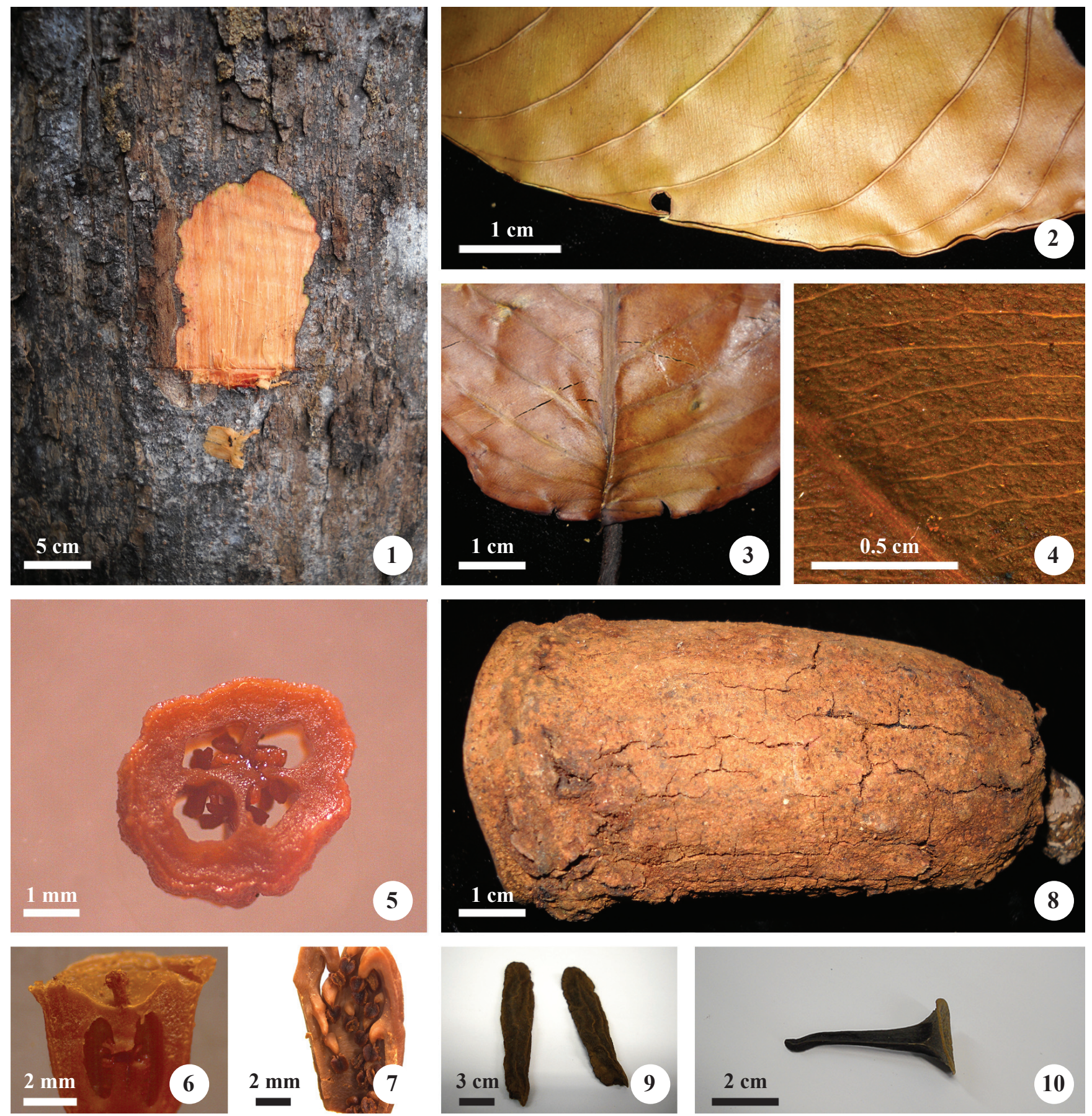

Figures 1-10. Allantoma lineata. 1. Outer and inner bark. 2. Leaf margins showing eucamptodromous venation. 3. Rounded leaf base. 4. Percurrent tertiary veins (non-reticulated). 5. 4-locular ovary in transversal section. 6. Ovary in longitudinal section, short style differentiated from the cupule of the ovary. 7. Stamens distributed at different levels along the stamen tube. 8. Cylindrical fruit. 9. Seeds with rugose tegument and caducous lateral wing. 10. Operculum with columella.

occurred during October and November. According to Mori \& Lepsh-Cunha (1995), this species is typical of humid environments and can be found growing along riverbanks in narrow waterways (igarapés) in seasonally flooded forests. It has been encountered in the Amazon regions of Venezuela, and in Brazil near Manaus, and occurs along the Amazon River to its mouth (Prance \& Mori 1979). This species was reported for the states of Amazonas and Pará in the INPA herbarium.

Material examined: BRAZIL. AmAzonAs: Manaus, Tupé Sustainable Development Reserve, 19-II-2011, L Matta et al. 26 (INPA). 
Additional material examined: BRAZIL. AmAzonAs: without locality, 31-III-1972, DF Coêlho s.n. (INPA); Manaus, 01-I-1984, BW Nelson 1348 (INPA).

Bertholletia Bonpl., P1. Aequinoct. 1: 122-127, tab. 36. 1807.

This genus is characterized by canopy and emergent trees; trunk cylindrical with deep fissures in the bark; leaves medium to large (20-30 cm long), glabrous, obovate to oblong; flowers zygomorphic; calyx with two sepals; 6 petals; hood with vestigial stamens turned inwards, without forming a spiral; filament clavate; ovary 4-locular, stigma long (up to $4 \mathrm{~mm}$ ) and geniculate. Fruit rounded, woody, with inconspicuous calicinal ring, small operculum, functionally indehiscent. Seeds triangular in transversal section; is the only species with a hard and woody seed testa, without funicle. This genus is monospecific and is found in the Guianas and in the Amazon forests of Columbia, Venezuela, Peru, Bolivia, and Brazil.

2. Bertholletia excelsa Bonpl., P1. Aequinoct. 1: 122, tab. 36. 1807.

Figures 11-21

Trees $15 \mathrm{~m}$ tall. Trunk and base cylindrical; outer bark gray, deeply fissured, without lenticels; inner bark yellow. Leaf with shiny adaxial face, abaxial face whitish; petiole with trichomes, canaliculate, 15-29 mm long; leaf blade obovate or oblong, 20-30 $\times$ 9-13 cm, glabrous, coriaceous; base rounded; margins entire or slightly crenulate; apex cuspidate; venation brochidodromous; midrib prominent on adaxial face and salient on abaxial face. Inflorescence terminal, paniculate, with trichomes, 11-24 cm long; pedicel with trichomes, 1-2 mm long. Flowers zygomorphic; calyx with 2 sepals, wide-elliptical, $8.5-10.5 \times 7.0-8.5 \mathrm{~mm}$, green; petals 6 , obovate or ovate, $31-33 \times 14-17 \mathrm{~mm}$, imbricate, white or light-yellow; hood thick at apex with appendages curved inwards; stamen ring with 100 to 120 stamens, filaments clavate, 3-4 mm long, anthers rimose, 0.8-1.0 mm long; ovary inferior, 4-locular, 3-4 ovules per locule, axial placentation, stigma geniculate, well differentiated from the cupule of the ovary, $4 \mathrm{~mm}$ long. Fruit dehiscent, globose, 10.0-12.5 × 10.0-12.5 cm, calyx not persistent on the mature fruit, operculum without columella. Up to 25 seeds per fruit, $3.5-5.0 \times 2.0 \mathrm{~cm}$, with thick and rugose testa.

Bertholletia excelsa has large leaves (up to $30 \mathrm{~cm}$ long, the largest yet encountered in the Tupé SDR), small spacing between the secondary veins, and the flower has a hood with appendages turned inward (although not forming a spiral). Mori \& Lepsch-Cunha (1995) described this species as having a cylindrical trunk with deeply fissured bark; abaxial face of the leaves whitish; calyx with two lobes and rounded fruit that detach at maturity still containing the seeds. According to Mori \& Prance (1990), this species is easily distinguished from the others by having rounded fruit that fall at maturity while still containing the intact seeds due to the fact that the diameter of the opercular opening is smaller than the seeds - making these fruit functionally indehiscent (Prance \& Mori 1978). The seeds are removed from the interior of the fruit by rodents with strong teeth, such as agoutis (Dasyprocta spp.). Mori \& Prance (1990) emphasized that this combination of triangular seeds, woody testa, and an undifferentiated embryo was only encountered in this species. The stamens of Bertholletia excelsa are vestigial and oriented toward the interior of the hood, where nectar is produced; this type of hood is exclusive to this genus. Maués (2006) noted that the hood of the androecium fits snugly against the cupule of the ovary and the petals exert pressure on the sides of the androecium, thus blocking entrance to the flower - and only the most robust bees of the genera Bombus, Centris, Epicharis, Eulaema, and Xylocopa are strong enough to dislocate the hood and effectively pollinate Bertholletia flowers. Other floral characters important for differentiating $B$. excelsa include the presence of two sepals (exclusive to the genus); the other species of Lecythidaceae generally have six sepals.

Bertholletia excelsa was encountered flowering in the Tupé SDR in January in terra-firme upland forest. Mori \& Lepsch-Cunha (1995) reported its flowering period as being from October to December, with fruiting being observed in January and February. The same authors noted that this species is typical of nonflooding environments and is encountered in the Guianas and in the Amazon forests of Columbia, Venezuela, Peru, Bolivia, and Brazil (Mori et al. 2010). The INPA herbarium contains specimens from the Brazilian states of Acre, Amazonas, Mato Grosso, Pará, Rondônia, and Roraima.

Material examined: BRAZIL. AmAzonAs: Manaus, Tupé Sustainable Development Reserve, 19-I-2011, Matta et al. 21 (INPA).

Additional material examined: BRAZIL. AmAZonAs: Manaus, Uatumã river, 24-XI-1956, W Rodrigues 243 (INPA); Aleixo road, 28-X-1974, GT Prance \& JF Ramos s.n. (INPA). Mato Grosso: without locality, Codemat road, km 3, 7-X-1976, S Miranda 341 (INPA). 
Couratari Aubl., Hist. Pl. Guiane 2: 723-724, tab. 290. 1775.

Genus characterized by canopy and emergent trees; leaves small to medium (3-20 cm long), glabrous or pubescent. Flowers zygomorphic, with 6 sepals and 6 petals; hood totally rolled into a spiral, with an external flap that develops at the apex of the spiral; ovary with 3 locules, ovules numerous; fruit of the pyxidium type, cylindrical with a relatively thin pericarp; seeds circumferentially alate.
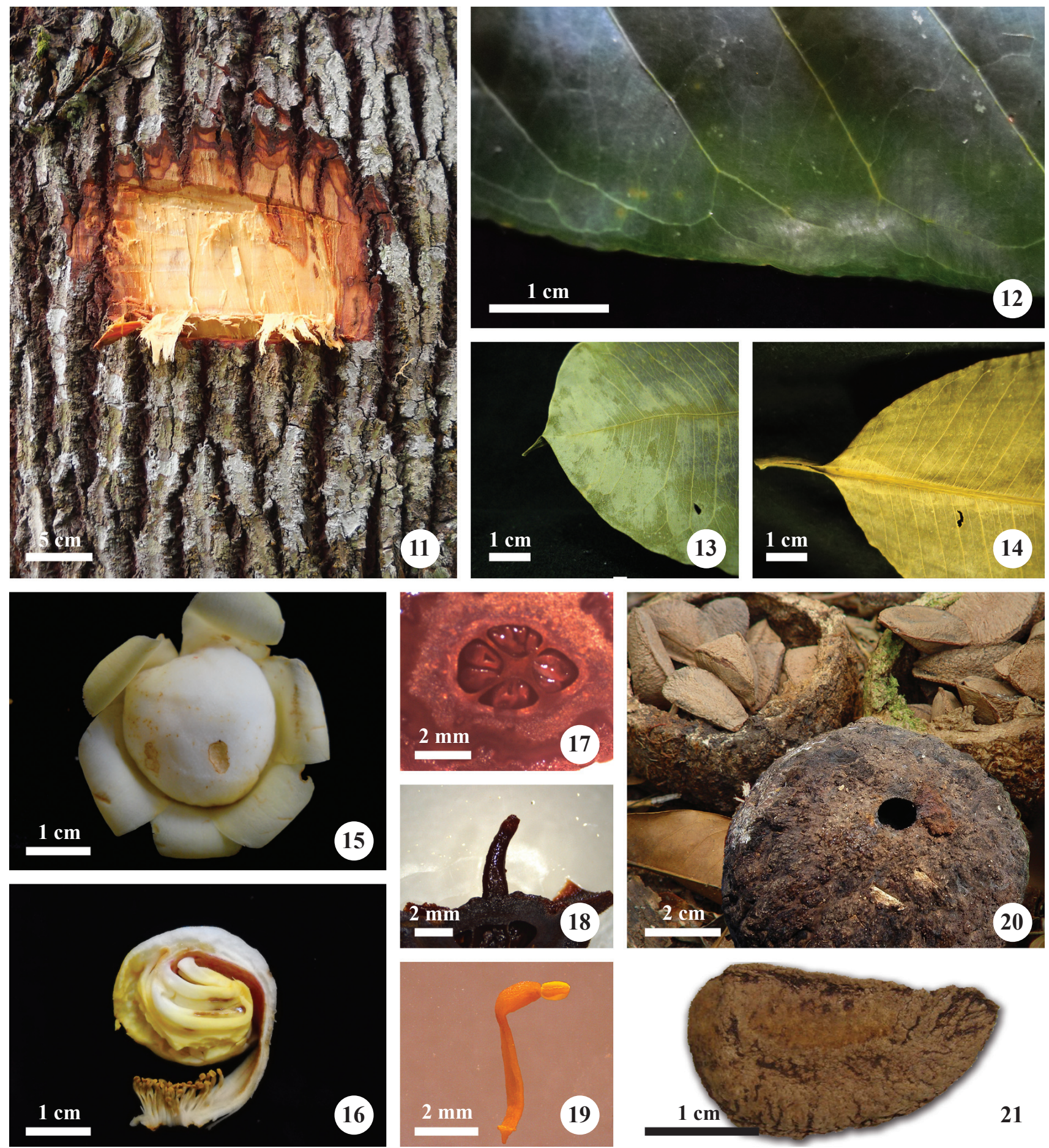

Figures 11-21. Bertholletia excelsa. 11. Outer and inner bark. 12. Leaf margin slightly crenulate. 13. Leaf apex cuspidate. 14. Base rounded. 15. Flower in apical view. 16. Androecium in longitudinal section showing the appendages of the hood turned inwards, but without forming a full spiral. 17. 4-locular ovary. 18. Style geniculate and well differentiated from apex. 19. Stamen with clavate filament. 20. Round fruits with small opercular openings. 21. Seed with woody testa. 
This neotropical genus comprises 19 species distributed through Central America (Costa Rica and Panama), the western Andes (Colombia), throughout the Amazon basin and in the coastal forests of the Brazilian states of Bahia, Espírito Santo, and Rio de Janeiro. Only a single species of the genus was encountered in the Tupé SDR.

3. Couratari tenuicarpa A.C.Sm., Brittonia 2: 158. 1936.

Figures 22-31

Trees $12 \mathrm{~m}$ or taller. Trunk cylindrical, buttressed, outer bark gray, with superficial vertical fissures, with lenticels; inner bark dark-yellow. Leaves with adaxial face shiny and abaxial face dull; petiole glabrous, flat convex, 9.0-16.8 mm long; leaf blade elliptical, 7.0-9.5 × 4.0$5.0 \mathrm{~cm}$, glabrous, coriaceous; base obtuse; margins entire or slightly crenulate; apex short acuminate; venation brochidodromous; midrib little prominent on adaxial face, prominent on abaxial face. Inflorescence terminal, racemose, with trichomes, $3.9-9.5 \mathrm{~cm}$ long; pedicel with trichomes, 10-22 mm long. Flowers zygomorphic; calyx with 6 sepals, triangular, 2.5-3.5 × 2.5-3.0 mm, valvate, dark-pink; petals 6 , obovate or spatulate, $16-24 \times$ 7-12 mm, imbricate, light-pink; hood with double internal spiral that develops an extra tip; stamen ring with 20 to 25 stamens, filaments straight, 0.2-0.4 mm long, anthers rimose, 0.3-0.5 mm long; ovary inferior, trilocular, 6-10 ovules per locule, placentation axial, ovary umbonate, stigma $0.5 \mathrm{~mm}$ long, style poorly differentiated. Fruit dehiscent, cylindrical, $4-5 \times 1-1.5 \mathrm{~cm}$, calyx not persistent on mature fruit, operculum with columella. Seeds 3.5-4 × 1.2-1.5 cm, aril flattened, forming a wing surrounding the entire seed.

The principal characteristics used to recognize this species include a buttressed trunk; small leaves with slightly crenate margins; flowers with hood with a double spiral with a spongy external tip; fruit small (up to $5 \mathrm{~cm}$ long) and slightly triangular in transversal section; the seeds have a membranous and flattened aril, forming a wing that totally surrounds the seed (a characteristic typical of anemochorous seeds). Couratari tenuicarpa has vestigial stamens that produce nectar at the apex of the hood, and this plant is apparently pollinated by Euglossinae bees (Mori \& Prance 1981) as these animals have long buccal organs that allow them to retrieve nectar from the interior of the hood. Couratari was divided into three sections (Echinata, Couratari and Microcarpa) by Mori \& Prance (1990) according to their type of external flap, the characteristics of the fruit (such as hardness and woodiness), and the types of trichomes. Couratari tenuicarpa was included in the section Microcarpa as it has a hood that is doublespiraled inwardly, with an external labelate flap which in the case of $C$. tenuicarpa is also spongy; it also has coriaceous fruits, and does not have stellate trichomes. Due to the great similarity between some species of this section, the superspecies Couratari multiflora was created that includes C. multiflora (Sm.) Eyma, C. oligantha A.C.Sm., C. riparia Sandwith, and $C$. tenuicarpa. Mori \& Prance (1990) noted that the flowers of these species are very similar and they differ from each other by only a few characteristics of their leaves (such as their texture and shape, and the size of the petiole) and their fruit. The species most likely to be confused with $C$. tenuicarpa is $C$. riparia, as they are both trees that occur in temporarily flooded environments; these two species differ in terms of the length of their petioles and the shapes of their fruit. The petiole of $C$. tenuicarpa is up to $17 \mathrm{~mm}$ long and its fruit cylindrical, while the petiole of $C$. riparia is up to $9 \mathrm{~mm}$ long and its fruit are campanulate. These species are also allopatric, with $C$. riparia being restricted to Guiana while $C$. tenuicarpa is widely distributed in the central and western Amazon region. Couratari tenuicarpa may also be confused with C. oblongifolia Ducke \& R. Knuth due to similarities of their flowers, although these species differ in terms of the sizes of their fruits, which are smaller in C. tenuicarpa (up to $5 \mathrm{~cm}$ ) and in their habitats, as C. oblongifolia grows in non-flooding forests.

Couratari tenuicarpa was observed with flowers and fruit in July in the Tupé SDR, and was collected in the igapó forest area that is seasonally flooded by Tupé Lake, although it was not very abundant there. According to Mori \& Prance (1990), this species flowers from January to June and is typically found along the edges of rivers and lakes throughout the Amazon basin and in Suriname. There are records of this species in the INPA herbarium from collections made in the Brazilian states of Amazonas, Pará, and Rondônia.

Material examined: BRAZIL. AmAzonAs: Manaus, Tupé Sustainable Development Reserve, 10-VII-2010, LBV Matta \& J Valsko 06 (INPA).

Additional material examined: BRAZIL. PARÁ: without locality, 5-VII-1967, RE Schultes 24590 (INPA); Oriximiná, 18-VII-1980, CAC Ferreira 1640 (INPA).

Eschweilera Mart. ex DC., Prodr. 3: 293. 1828.

Genus characterized by small to large trees; trunk cylindrical, with or without large buttress roots; leaf blade 
glabrous with brochidodromous venation; petiole with flat-convex outline; flowers zygomorphic; calyx with 6 sepals; corolla with 6 petals; hood completely rolled up at least once; stamens free, forming a stamen ring, anthers rimose; ovary inferior, usually bilocular, rarely tetralocular, various ovules per locule, placentation axial; fruit of the pyxidium type, operculum without columella; seeds with lateral aril, rarely with basal aril.

This is the most abundant genus of Lecythidaceae, with 92 described species. It is also the most widely
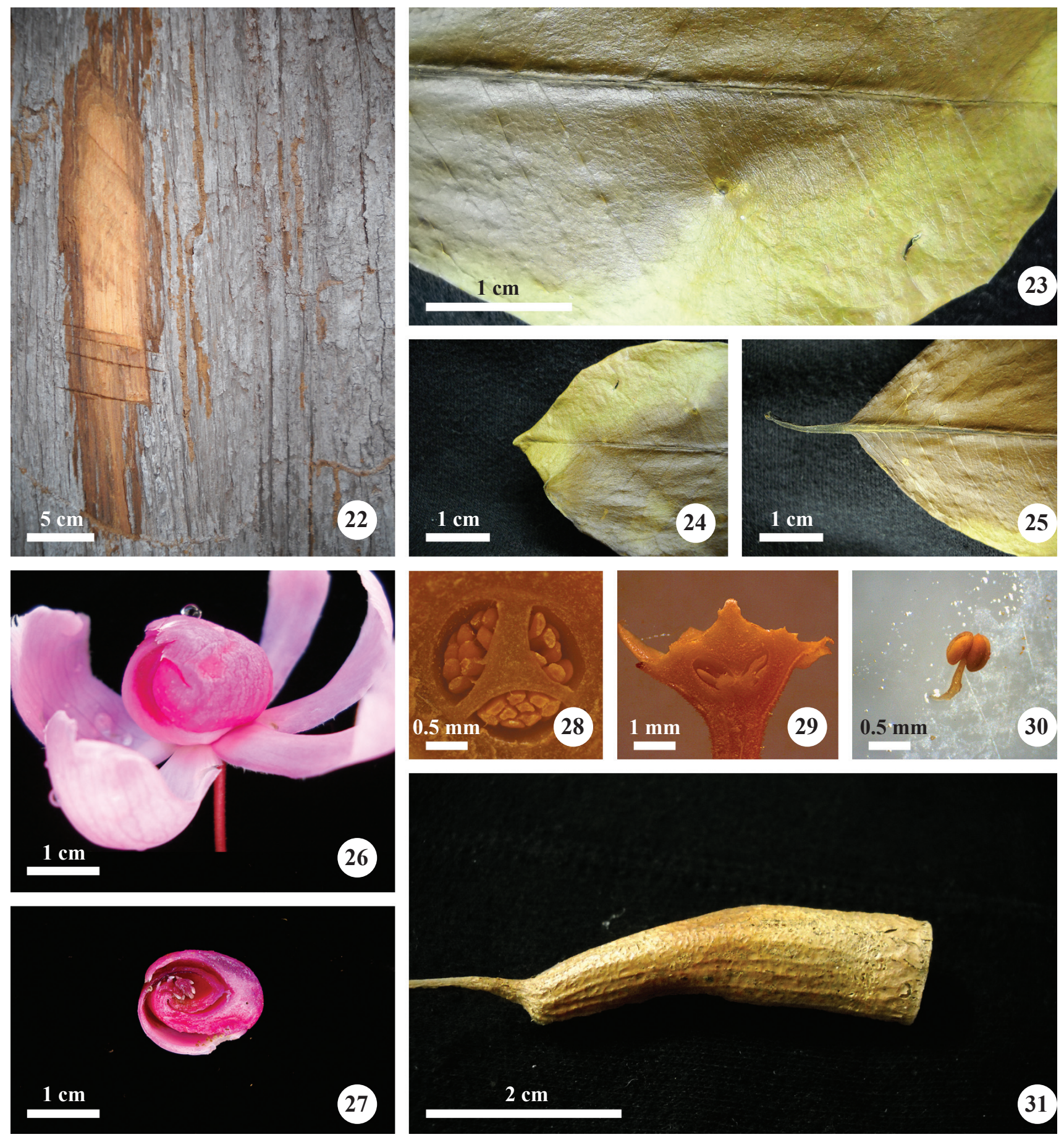

Figures 22-31. Couratari tenuicarpa. 22. Outer and inner bark. 23. Leaf with smooth margins and slightly prominent midrib. 24. Apex short-acuminate. 25. Base obtuse. 26. Flower in lateral view. 27. Androecium in longitudinal section showing the double spiral of the hood, with an external tip developing at the apex of the second spiral. 28. 3-locular ovary. 29. Ovary in transversal section, cupule of the ovary umbonate, with style little differentiated. 30. Stamen with straight filament. 31 . Fruit cylindrical, longitudinally striated. 
distributed genus, occurring in Mexico, Panama, and Costa Rica in Central America. It occurs along the Pacific coast of Colombia in South America, throughout the Amazon region and the Guianas, along the Atlantic coast of Brazil, as well as in the Cerrado and Caatinga biomes (Mori \& Prance 1990). Six species of Eschweilera were found in the Tupé SDR, making it the genus with the largest number of species in the reserve.

4. Eschweilera amazonica R.Knuth, in Engler Pflanzenr. IV. 219a (Heft 105): 109. 1939.

Figures 32-39

Trees $25 \mathrm{~m}$ tall. Trunk and base cylindrical; outer bark gray-brown, smooth or with superficial vertical fissures, without lenticels; inner bark reddish-yellow. Leaf shiny on adaxial face and dull on abaxial face; petiole glabrous, flat convex, 3.3-7.2 mm long; leaf blade elliptical, $6.0-11.0 \times 3.5-5.5 \mathrm{~cm}$, glabrous, coriaceous; base obtuse; margins entire; apex acuminate; venation brochidodromous; midrib prominent on both faces. Inflorescence terminal, racemose, in zigzag, with trichomes, 5.0-6.5 cm long; pedicel with trichomes, 1-2 mm long. Flowers zygomorphic; calyx with 6 sepals, ovate, $3.0-5.2 \times 3.5-4.5 \mathrm{~mm}$, imbricate, green; petals 6 , obovate or ovate, $14.0-21.0 \times 9.0-12.3 \mathrm{~mm}$, imbricate, yellows; hood rolled-up twice inwardly; stamen ring with ca. 300 stamens, filaments clavate, 0.8-1.7 mm long, anthers rimose, 0.3-0.4 mm long; ovary inferior, bilocular, up to 13 ovules per locule, placentation axial, ovary umbonate, stigma $1 \mathrm{~mm}$, style poorly differentiated. Fruit dehiscent, campanulate, 6.0$11.0 \times 3.0-5.5 \mathrm{~cm}$, calyx persistent on the mature fruit, operculum without columella. Seeds 1-4 per fruit, 2.2$3.0 \times 0.9-1.3 \mathrm{~cm}$, aril fleshy in basal region.

This species can be recognized by its cylindrical trunk, smooth bark in the younger plants, with superficial vertical fissures in older plants; leaves small (6$11 \mathrm{~cm}$ long) with prominent midrib on both faces; fruit campanulate and seeds with basal aril. According to Mori \& Prance (1990), E. amazonica is morphologically similar to E. amazoniciformis S.A. Mori, with which it shares campanulate fruit and similar androecium structures, as well as being among the very few species of the genus that have seeds with a basal aril. They differ in that E. amazonica has flowers with six petals while the flowers of E. amazoniciformis are tetramerous; additionally, the former species has larger leaves that are less coriaceous, with apices that are less acuminate than in E. amazoniciformis. Prance \& Mori (1979) pointed out that all the species of the genus Eschweilera are characterized by having hoods that are completely rolled-up inwardly at least once. In all the species of the genus Eschweilera so far examined, the hood was a double internal spiral; Mori et al. (2010) noted that in species with this type of hood the proximal appendages are vestigial, with rudimentary anthers, while the distal appendages have vestigial anthers that produce nectar. Mori \& Prance (1981) pointed out that the principal pollinators of these types of flowers are Euglossinae bees, with long buccal structures that allow them to reach the nectar within the hood. These authors also suggested that this type of hood may be a response to selection pressure exerted by Euglossinae bees - and that both these bees and the species of Lecythidaceae with this type of androecium are restricted to the Neotropical region.

Mature fruit of E. amazonica were collected in the Tupé SDR in February in upland terra-firme forests; various individuals were observed fruiting at that time, but they could not be collected because the fruits had been destroyed by monkeys. This was the only upland species encountered in the present study that was not recorded in the Flora of the Ducke Reserve and in the Reserva 1501 of the PDBFF program. Mori \& Prance (1990) found mature fruits on this species during the period between August and November and flowers between November and January in upland forests, but different from the observations made at the SDR, these authors noted that this species was quite rare in the area. According to Mori \& Prance (1990), E. amazonica is distributed in the central and eastern region of the Brazilian Amazon, and Smith et al. (2010) reported that this species is endemic to Brazil and is found in the states of Amazonas, Amapá, Pará, Rondônia, and Roraima. The INPA herbarium has records of this species from the states of Amazonas, Mato Grosso, Pará, Rondônia, and Roraima.

Material examined: BRAZIL. AmAzonAs: Manaus, Tupé Sustainable Development Reserve, 19-II-2011, L Matta et al. 27 (INPA); 19-II-2011, L Matta et al. 28 (INPA).

Additional material examined: BRAZIL. PARÁ: without locality, 4-XII-1970, W Rodrigues 8991 (INPA); Tucuruí, 1-IX-1983, FE Miranda 355 (INPA).

5. Eschweilera atropetiolata S.A.Mori, Fl. Neotrop. Monogr. 21(2): 241. 1990.

Figures 40-50

Trees $25 \mathrm{~m}$ tall. Trunk and base cylindrical; outer bark gray-brown, with thin and narrow plaques, without lenticels; inner bark red. Leaf with adaxial face dull and abaxial face dull and whitish; petiole with trichomes, 
flat-convex, 12-17 mm long; leafbladeellipticaloroblong, $14.5-17.5 \times 6.5-8.5 \mathrm{~cm}$, glabrous, coriaceous; base rounded; margins entire; apex short-acuminate; venation brochidodromous; midrib prominent on the adaxial face and salient on the abaxial face. Inflorescence terminal, racemose, with trichomes, $2-10 \mathrm{~cm}$ long; pedicel with trichomes, 3-8 mm long. Flowers zygomorphic; calyx with 6 sepals, triangular, 4.5-7.0 × 3.5-7.0 $\mathrm{mm}$, valvate,
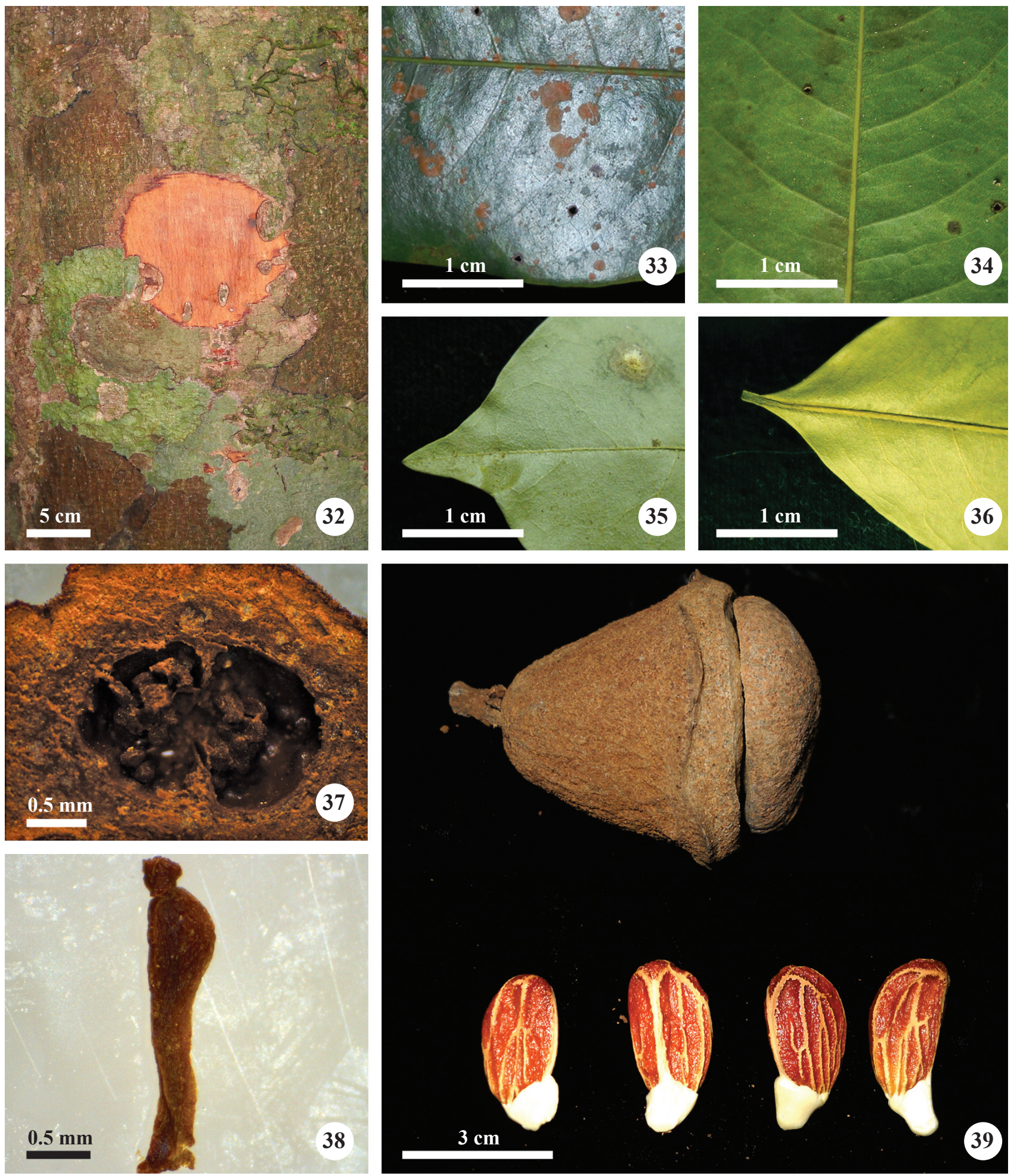

Figures 32-39. Eschweilera amazonica. 32. Outer and inner bark. 33. Adaxial face of the leaf shiny and with prominent midrib. 34. Abaxial face with prominent midrib. 35. Apex acuminate. 36. Base decurrent. 37. 2-locular ovary. 38. Stamen with clavate filament. 39. Fruit campanulate, seeds with fleshy basal aril. 
green; petals 6, obovate or ovate, $24-35 \times 15-22 \mathrm{~mm}$, imbricate, white or cream colored; hood with double inward spiral; stamen ring with ca. 300 stamens, filaments straight, $1.8-2.7 \mathrm{~mm}$ long, anthers rimose,
0.5-0.7 mm long; ovary inferior, bilocular, 7-9 ovules per locule, placentation axial, ovary umbonate, stigma $1.2 \mathrm{~mm}$, style poorly differentiated. Fruit dehiscent, obconical to campanulate, $3.0-5.5 \times 3.3-5.0 \mathrm{~cm}$, calyx
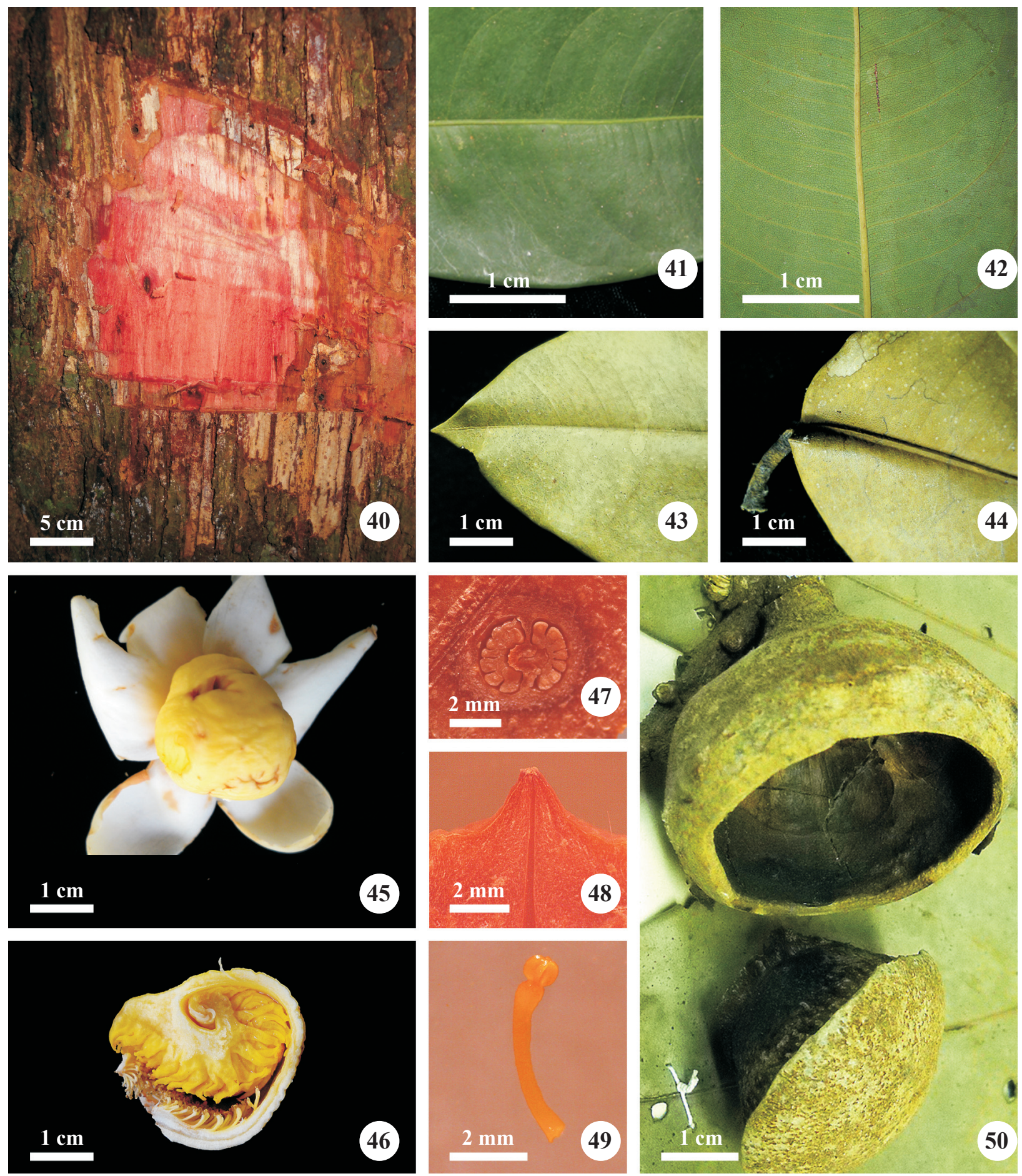

Figures 40-50. Eschweilera atropetiolata. 40. Outer and inner bark. 41. Leaf margin entire, adaxial face with prominent midrib and secondary and tertiary veins little evident. 42. Abaxial face of the leaf with salient midrib. 43. Leaf apex acuminate. 44. Base rounded. 45. Flower in apical view. 46. Androecium in longitudinal section, showing the hood with a double spiral. 47. 2-locular ovary. 48. Ovary umbonate in longitudinal section, style little differentiated. 49. Stamens with clavate filaments in distal region. 50. Cup-shaped fruit, without columella. 
persistent in the mature fruit, operculum without columella. Seeds with fleshy lateral aril.

This species can be recognized by its outer bark with thin vertical striations, red inner bark; leaves with whitish abaxial face that develops dark blotches after being removed from the tree; flowers white; fruit campanulate and seeds with lateral aril. According to Mori \& Prance (1990), this species is characterized by having a relatively long petiole, abaxial face with papilose cuticle that gives it a glaucous aspect; androecium with double and vertically oriented spiral, and fruit with rough light-brown exocarp. Mori \& Lepsh-Cunha (1995) noted that the principal characteristics of this species also include slightly fissured bark, long and blackish petioles, and leaves with a whitish abaxial face, which, according to these authors, is caused by the presence of a very thick and ornamented cuticle (considered a papilose cuticle).

Eschweilera atropetiolata was observed flowering in January and February in the upland terra-firme forests in the Tupé SDR, although few individuals grew there. Mori \& Prance (1990) observed flowering in this species during the months of December to May, but also noted that some flowering material was collected in September; these authors also noted that the most common habitats of this species were non-flooding forests. Mori \& Lepsch-Cunha (1995) reported a flowering period for this species between January and November, with fruiting from March to November, and noted that E. atropetiolata is encountered in the central Amazon region; according to Smith et al. (2010), this is the only species endemic to Brazil and is encountered only in the states of Amazonas and Rondônia. They were specimens in the INPA herbarium from the states of Amazonas and Rondônia.

Material examined: BRAZIL. AmAzonAs: Manaus, Tupé Sustainable Development Reserve, 19-II-2011, $L$ Matta et al. 25 (INPA).

Additional material examined: BRAZIL. AmAZONAS: without locality, 27-III-1995, CA Sothers 373 (INPA); Manaus, 1-VIII-2001, E Pereira 42 (INPA); 9-VI-1965, $W$ Rodrigues 7111 (INPA); Novo Aripurã, 23-IV-1985, CAC Ferreira 5704 (INPA).

6. Eschweilera coriacea (DC.) S.A.Mori, Fl. Neotrop. Monogr. 21(2): 203. 1990.

Lecythis coriacea DC., Prodromus 3: 291. 1828.

Figures 51-62

Trees $27 \mathrm{~m}$ tall. Trunk cylindrical, buttressed, outer bark dark-brown, with little sloughing, lenticels aligned vertically; inner bark yellow. Leaf with adaxial face shiny and abaxial face dull; petiole with trichomes, flat convex, 6.5-10.4 mm long; leaf blade elliptical, 14.5$22.0 \times 6.0-7.0 \mathrm{~cm}$, glabrous, coriaceous; base rounded or cuneate; margins entire; apex long-acuminate or acuminate; venation brochidodromous; midrib flat on the adaxial face and salient on the abaxial face. Inflorescence terminal, paniculate, in zigzag, with trichomes, 5.5-11.5 cm long; pedicel with trichomes, 17.0-20.5 mm long. Flowers zygomorphic; calyx with 6 sepals, ovate, $4.0-5.0 \times 3.0-3.6 \mathrm{~mm}$, valvate, green; petals 6 , obovate or ovate, $12-16 \times 9-13 \mathrm{~mm}$, imbricate, light-yellow; hood with double inward spiral; stamen ring with 170 to 280 stamens, filaments straight, 0.9$1.2 \mathrm{~mm}$ long, anthers rimose, $0.5 \mathrm{~mm}$ long; ovary inferior, bilocular, 5-7 ovules per locule, placentation axial, ovary umbonate, stigma 1.5-2.0 mm long, style poorly differentiated. Fruit dehiscent, subglobose, 1.5$2.4 \times 3.4-4.8 \mathrm{~cm}$, calyx persistent on the mature fruit, operculum without columella. Up to 10 seeds per fruit, 2.1-2.4 × 1.4-1.7 cm, with fleshy lateral aril.

This species is recognized by its buttressed trunk, outer bark dark-brown and inner bark yellow; sepals with margins frequently reddish; fruit subglobose and seeds with fleshy lateral aril. According to Mori \& Prance (1990), the recognition of this plant in the field is facilitated by its dark-brown to black bark; flowers with sepals slightly gibose, that is, sepals tomentose at their base; hood of the androecium yellow, forming a double spiral, and fruit with an erect supracalicinal zone and frequently a truncated infracalicinal zone. Eschweilera coriacea is often confused with E. truncata due to similarities in their vegetative characters; this confusion occurs because both plants have trunks that are very dark-brown and show little sloughing, and very similar leaves; it is possible to differentiate between these two species due to a number of divergent characteristics: E. coriacea normally has vertically oriented lenticels on the trunk and often has large buttress roots, the midrib is flat on the adaxial face of the leaf and salient on the abaxial face, with trichomes, with brownish spots scattered on the entire leaf blade; E. truncata, on the other hand, does not have large buttressed nor lenticels on its trunk, its leaves have a glabrous midrib that is prominent on the adaxial face and salient on the abaxial face, and when there are spots on the abaxial face they are well-spaced from each other. According to Hopkins \& Mori (1999), E. coriacea is vegetatively very similar to $E$. truncata, differing from the latter by having leaves with flat midribs on the adaxial face and salient midribs (with trichomes) on the face abaxial; in E. truncata the 
midrib is salient and glabrous on both faces. Mori \& Lepsch-Cunha (1995) also noted that the tertiary veins of $E$. coriacea are only slightly salient, the sepals are thicker and not imbricate, and their fruits are larger (up to $4.8 \mathrm{~cm}$ wide) and more woody than in E. truncata. Mori \& Lepsch-Cunha (1995) additionally noted that in the taxonomic treatment of Eschweilera in the Flora
Neotropica (Mori \& Prance, 1990), E. truncata was cited as a synonym of $E$. coriacea, but fieldwork and studies of the type specimen of $E$. coriacea indicated the necessity of re-validating $E$. truncata.

Eschweilera coriacea was collected with flowers in October only in the upland terra-firme forest in the Tupé SDR; this corroborates the observations of Mori

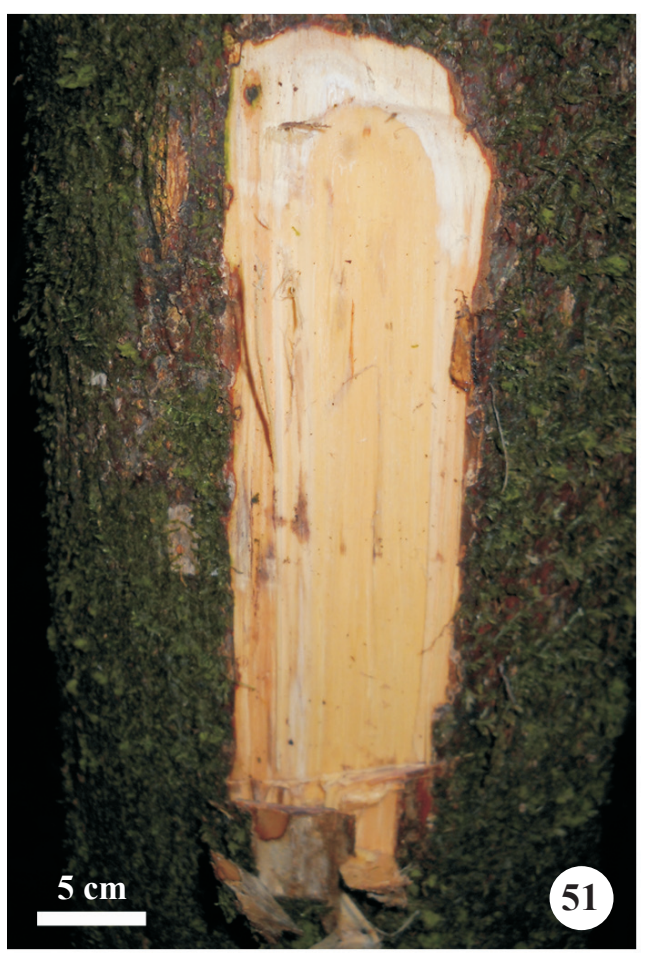

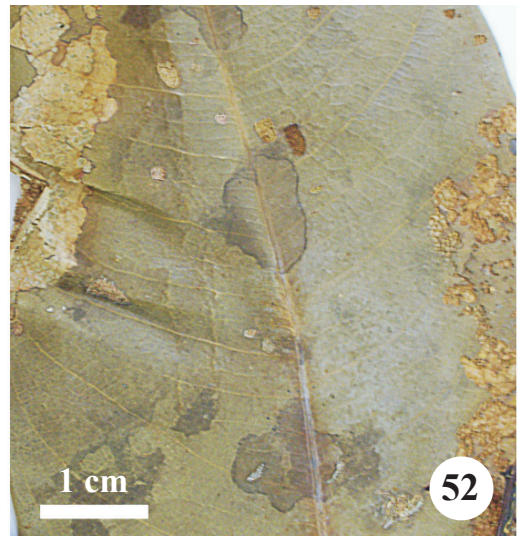
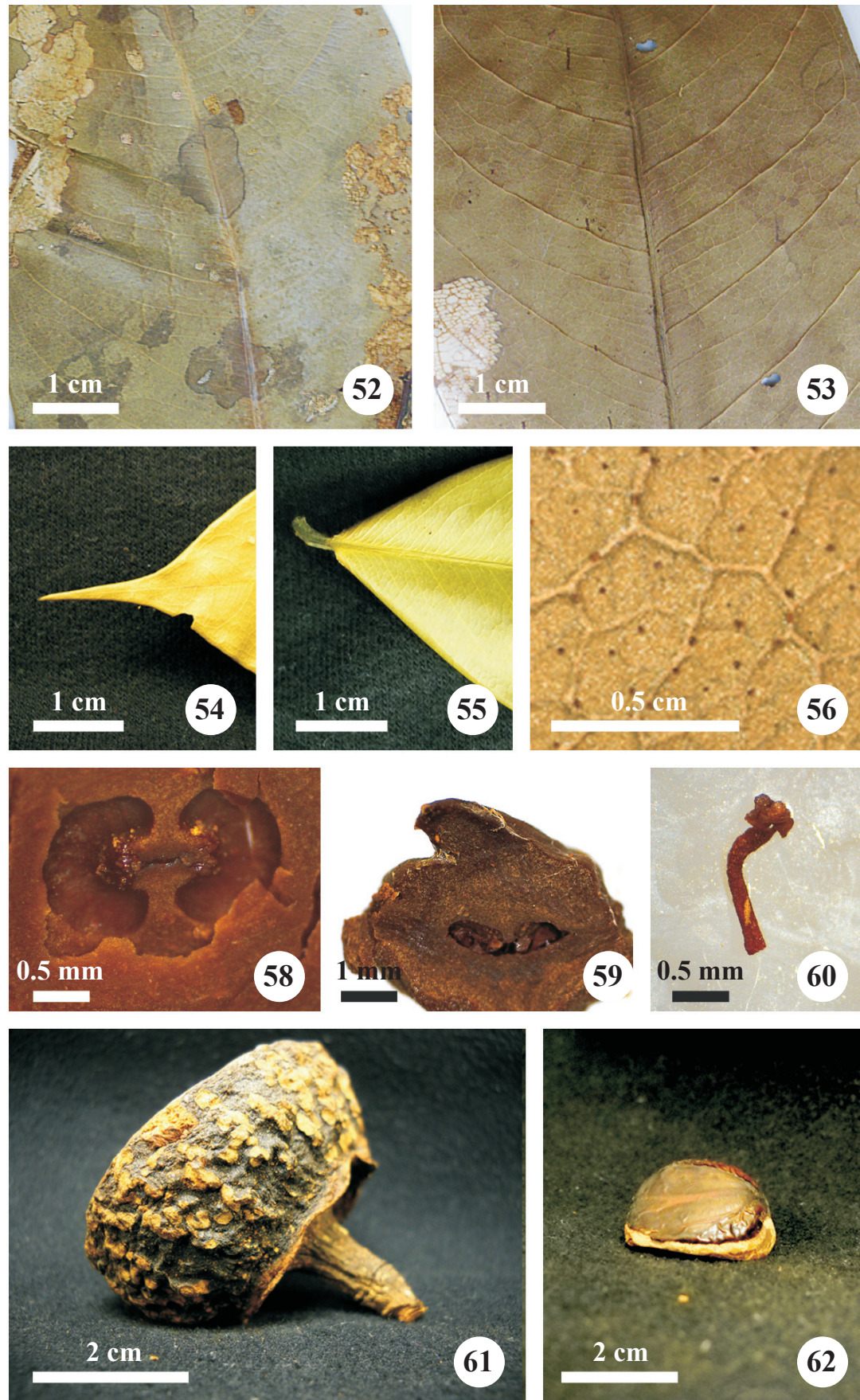

Figures 51-62. Eschweilera coriacea. 51. Outer and inner bark. 52. Adaxial leaf surface with flat midrib. 53. Abaxial leaf surface with salient midrib. 54. Apex long-acuminate. 55. Base cuneate. 56. Abaxial leaf surface with spots. 57. Inflorescence with long pedicel. 58. 2-locular ovary. 59. Ovary in longitudinal section with cupule umbonate and style little differentiated. 60. Stamen with straight filament. 61. Fruit subglobose. 62. Seed with fleshy lateral aril. 
\& Lepsch-Cunha (1995), who reported flowering individuals from October to November and fruit in January and February. Mori \& Prance (1990) also observed individuals of this species growing in periodically flooded forests. Eschweilera coriacea is one of the most widely distributed and abundant species of the family, being encountered in the Guianas and Panama, and throughout the Amazon region. According to Mori et al. (2010), E. coriacea is the most common species of Lecythidaceae in the central Amazon region, thus making it one of the most ecologically important species in the family. Field observations as well as phytosociological projects have shown it to be one of the most abundant species of that family in the Tupé SDR. The INPA herbarium contains collections of this species from Brazil (Acre, Amazonas, Amapá, Maranhão, Mato Grosso, and Roraima), Bolivia, Colombia, the Guianas, and Suriname.

Material examined: BRAZIL. AmAzonAs: Manaus, Tupé Sustainable Development Reserve, 11-X-2005, $R A$ Borges 49 (INPA); 11-X-2005, RA Borges 55 (INPA).

Additional material examined: BRAZIL. AmAZONAs: Manaus, Distrito agropecuário - Reserva 1501 (km 41), 3-II-1990, NML Cunha 895 (INPA); 4-IV-1962, W Rodrigues 3578 (INPA).

7. Eschweilera tenuifolia (O.Berg) Miers, Trans. Linn. Soc. London 30: 255. 1874.

Lecythis tenuifolia O.Berg, Fl. bras. 14(1): 502. 1858. Figures 63-72

Trees $15 \mathrm{~m}$ tall. Trunk and base cylindrical; outer bark grayish-brown, fissured, without lenticels; inner bark dark-yellow. Leaves with both faces dull; petiole glabrous, flat convex, 4-6 mm; leaf blade oblong, 7.0$20.0 \times 3.0-5.5 \mathrm{~cm}$, glabrous, coriaceous; base obtuse; margins entire; apex short-acuminate or acute; venation brochidodromous; midrib prominent on both faces. Inflorescence terminal, racemose, with trichomes, $4 \mathrm{~cm}$ long; pedicel with trichomes, 2-3 mm long. Flowers zygomorphic; calyx with 6 sepals, triangular, $3 \times 3$ $4 \mathrm{~mm}$, imbricate, yellow with reddish margins; petals 6, obovate, 17-23 × 14-15 mm, imbricate, light-yellow; hood with double inward spiral; stamen ring with ca. de 200 stamens, filaments clavate, $1.5 \mathrm{~mm}$ long, anthers rimose, $0.5 \mathrm{~mm}$ long; ovary inferior, bilocular, 29-31 ovules per locule, placentation axial, ovary umbonate, stigma 1.0-1.5 mm long, style poorly differentiated. Fruit dehiscent, subglobose, 3.5-5.5 × 4.5-6.8 cm, calyx not persistent in the mature fruit, operculum without columella. Seeds $30-50$ per fruit, $2-2.7 \times 0.8-1.3 \mathrm{~cm}$.
This species is characterized by a cylindrical trunk; outer bark fissured, inner bark dark-yellow; leaves with prominent midrib on both faces; inflorescence and pedicel with trichomes; fruit subglobose and seeds angular, cuneiform, completely surrounded by a fleshy aril. Eschweilera tenuifolia is a unique species within the genus as it is the only one with angular cuneiform seeds, which makes it easily recognizable and motivating Mori \& Prance (1990) to create the section Jugastrum, which is represented only by this species. The same authors suggested that the seeds of this species fall into the seasonal flood waters when the operculum opens (floating for at least four months) and are carried by the river currents; these authors also noted that the fruit are frequently attacked by rodents that open the immature pyxidium with their teeth and consume the immature seeds. This species was encountered flowering in December and with fruit in February in the Tupé SDR; it is a very common and abundant plant in the periodically inundated igapó forests, especially around Tupé lake. Mori \& Prance (1990) reported a flowering peak for this species from November to March and noted that it is commonly encountered in periodically inundated forests along the Amazonas, Negro, Solimões, and Orinoco rivers. The INPA herbarium has specimens of this species from many parts of Amazonas State as well as the states of Pará and Roraima.

Material examined: BRAZIL. AmAzonAs: Manaus, Tupé Sustainable Development Reserve, 11-XII-2010, L Matta \& WR Brito 20 (INPA).

8. Eschweilera tessmannii R.Knuth, in Engler, Pflanzenr. IV. 219a (Heft 105): 115. 1939.

Figures 73-82

Trees $28 \mathrm{~m}$ tall. Trunk and base cylindrical; outer bark gray, smooth or with small depressions, without lenticels; inner bark red. Leaf with adaxial face shiny and abaxial face dull; petiole with trichomes, flat convex, 7.5$12.0 \mathrm{~mm}$ long; leaf blade elliptical or narrow-elliptical, 8.5-12.5 × 3.0-6.0 cm, glabrous, coriaceous; base obtuse; margins entire; apex short-acuminate or acute; venation brochidodromous; midrib prominent on the adaxial face and salient on the abaxial face. Inflorescence terminal, racemose, with trichomes, $5-14 \mathrm{~cm}$ long; pedicel with trichomes, 3.5-7.2 mm long. Flowers zygomorphic; calyx with 6 sepals, ovate, 3.5-6.0 × 2.7-3.5 mm, valvate, green; petals 6 , obovate, $7.5-13.0 \times 6.7-8.6 \mathrm{~mm}$, imbricate, pink; hood with double inward spiral; stamen ring with ca. 150 stamens, filaments straight, $1 \mathrm{~mm}$, anthers rimose, $0.5 \mathrm{~mm}$ long; ovary inferior, bilocular, up to 5 ovules per 
locule, placentation axial, stigma geniculate, $1 \mathrm{~mm}$ long, well differentiated from the cupule of the ovary. Fruit dehiscent, obconical, 2-2.2 $\times 2.8-3.2 \mathrm{~cm}$, calyx persistent in the mature fruit, operculum without columella. Seeds with fleshy lateral aril.
This species is characterized by having a cylindrical trunk, the bark is smooth in younger individuals but with small depressions in adult specimens, inner bark red; leaves with prominent midrib on the adaxial face and salient midrib on the abaxial face; petals pink; fruit
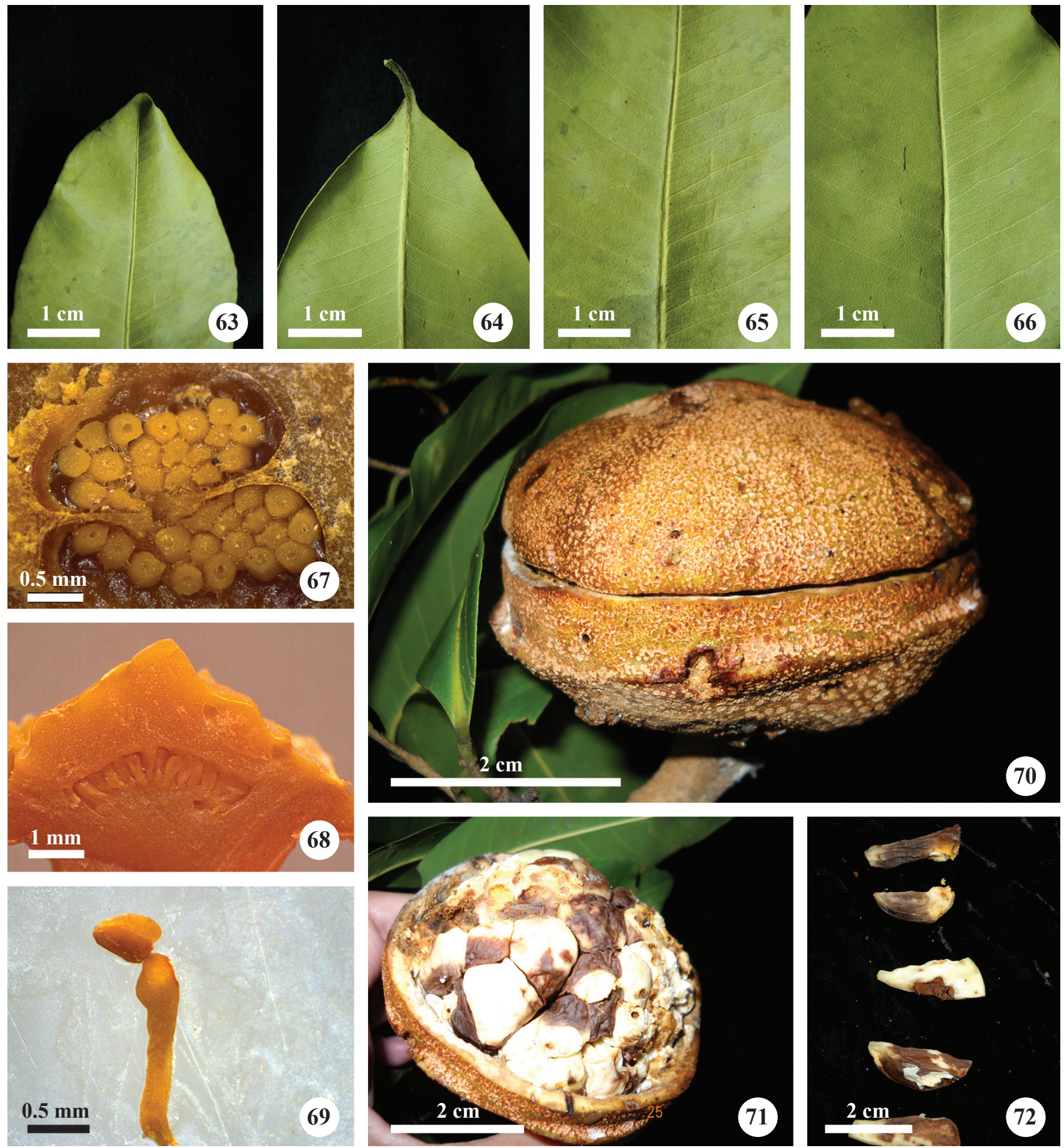

Figures 63-72. Eschweilera tenuifolia. 63. Leaf apex short-acuminate. 64. Leaf base obtuse. 65. Leaf with prominent midrib on adaxial surface. 66. Midrib prominent on abaxial surface. 67. 2-locular ovary. 68. Ovary in longitudinal section with cupule umbonate and style little differentiated. 69. Stamen with clavate filament. 70. Fruit subglobose. 71. Fruit without operculum, showing the placement of the seeds. 72 . Seeds. 
relatively small, goblet-shaped. According to Mori \& Prance (1990), this species differs from the others by having relatively small flowers and leaves, inflorescence axis, pedicel, and hypanthium with rust-colored trichomes and relatively long and geniculate stigmas.
Can be confused with Eschweilera apiculata (Miers) A.C.Sm. because of the similarities of their leaves and by the fact that both frequently have pinkish flowers; they differ from one another as the outer bark of $E$. apiculata peels off in plaques.
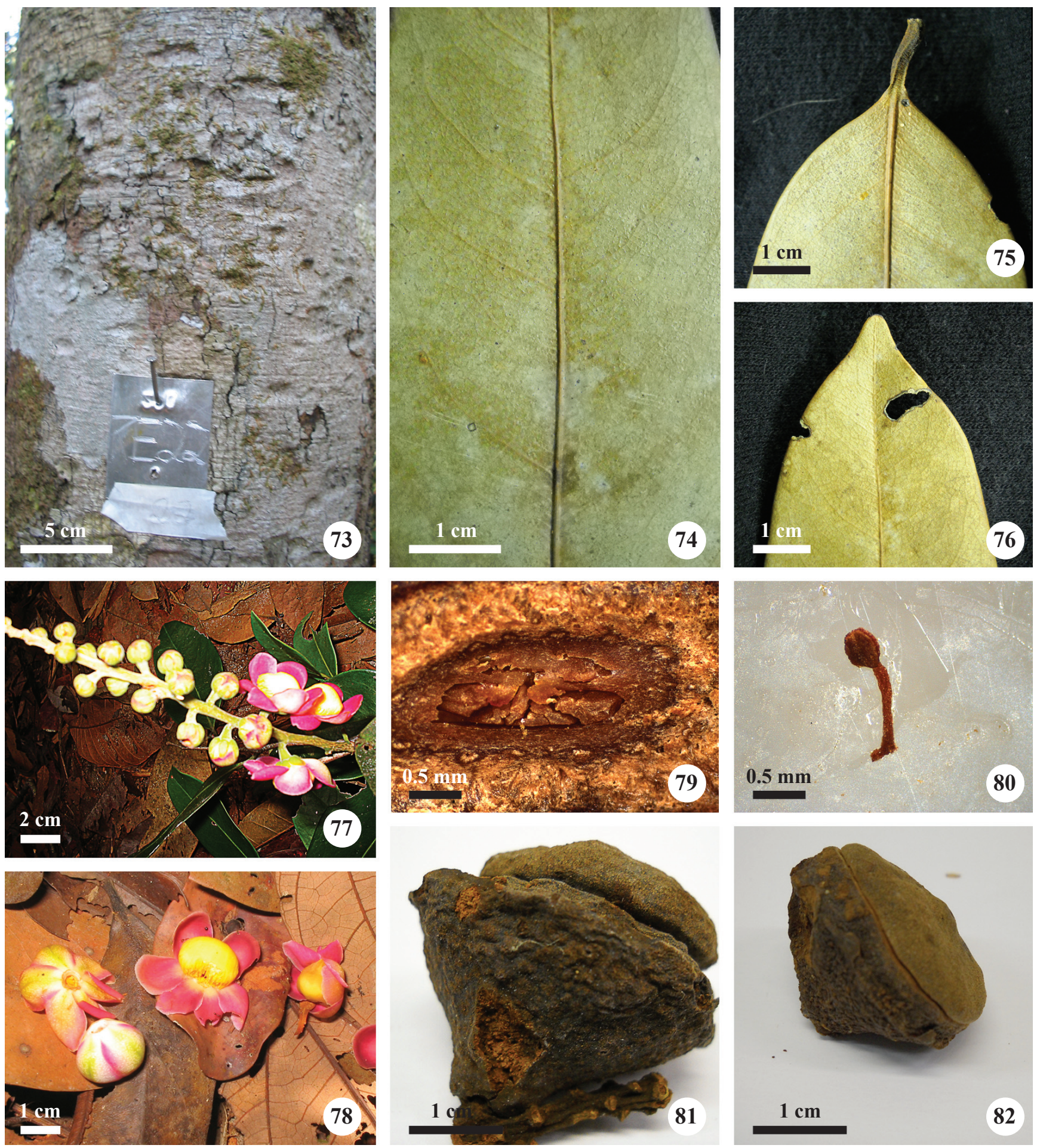

Figures 73-82. Eschweilera tessmannii. 73. Outer bark. 74. Leaf with prominent midrib on adaxial surface. 75. Leaf base obtuse. 76. Apex short-acuminate. 77. Inflorescence racemose. 78. Flowers. 79. 2-locular ovary. 80. Stamen with straight filament. 81-82. Cup-shaped fruit. 
Flowers were collected in the Tupé SDR in August and September. Mori \& Lepsch-Cunha (1995) reported flowering from September to January, and Mori \& Prance (1990) recorded flowering from August to November. This species was frequently encountered in upland terrafirme forests in the Tupé SDR. Mori \& Prance (1990) also reported this species from non-flooded environments and mentioned that $E$. tessmannii is found in central and western Amazon region. In Brazil, this species occurs in the states of Amazonas, Acre, and Rondônia (Smith et al. 2010). There is also a specimen in the INPA herbarium that was collected in Roraima State.

Material examined: BRAZIL. AmazonAs: Manaus, Tupé Sustainable Development Reserve, 29-VIII-2005, $R A$ Borges 18 (INPA); 30-VIII-2005, RA Borges 22 (INPA); 13-X-2005, RA Borges 77 (INPA).

Additional material examined: BRAZIL. ACRE: Mâncio Lima, Isac road, ca. $7 \mathrm{~km}$ from the city, 24-III1992, CAC Ferreira et al.10924 (INPA). AMAzONAs: Jutaí, Rio Solimões, right border, near the mouth of Jutaí river, 6-V-1986, CAC Ferreira 7329 (INPA).

\section{Eschweilera truncata A.C.Sm., Bull. Torrey Bot. Club} 60(6): 382, tab. 21, fig. 2. 1933.

Figures 83-92

Trees $25 \mathrm{~m}$ tall. Trunk and base cylindrical; outer bark dark-brown, almost smooth, with thin vertical striations, without lenticels; inner bark yellow. Leaf with adaxial face shiny and abaxial face dull; petiole glabrous, flat convex, 7.5-11.0 mm long; leaf blade elliptical, 11.0$19.0 \times 4.5-7.0 \mathrm{~cm}$, glabrous, coriaceous; base obtuse; margins entire; apex long-acuminate or acuminate; venation brochidodromous; midrib prominent on the adaxial face and salient on the abaxial face. Inflorescence terminal, racemose, glabrous, 3.5-9.0 cm long; pedicel glabrous, 3.5-6.0 mm long. Flowers zygomorphic; calyx with 6 sepals, oblong, $6.3-8.7 \times 3.5-4.4 \mathrm{~mm}$, imbricate, green; petals 6, obovate, $20-30 \times 13-19 \mathrm{~mm}$, imbricate, light-yellow; hood with double inward spiral; stamen ring with 236 to 271 stamens, filaments straight, $0.8 \mathrm{~mm}$ long, anthers rimose, $0.4 \mathrm{~mm}$ long; ovary inferior, bilocular, 5-7 ovules per locule, placentation axial, stigma obconical, $1.1 \mathrm{~mm}$ long, differentiated from the cupule of the ovary. Fruit dehiscent, globose, $1.5 \times 4 \mathrm{~cm}$, calyx persistent in the mature fruit, operculum without columella. Two seeds per fruit, $1.8-2 \times 1.4-1.5 \mathrm{~cm}$, with fleshy lateral aril.

The principal characteristics of this species include a dark-brown trunk, with yellow inner bark; the rachis of the inflorescences glabrous and angular; stigma differentiated from the apex of the ovary; fruit globose, with persistent calyx and seeds with fleshy lateral aril. It can be vegetatively confused with Eschweilera wachenheimii (Benoist) Sandwith and E. bracteosa (Poepp. ex O.Berg) Miers, which also have dark trunks and yellow inner bark, however, E. wachenheimii trees are relatively small (up to $23 \mathrm{~m}$ ), and their branches form conspicuous straight angles from the trunk, while E. bracteosa has large leaves (up to $28 \mathrm{~cm}$ long).

Eschweilera truncata was collected with flowers from August to October, and was frequently encountered in the upland terra-firme forests in the Tupé SDR, being one of the typical species of this habitat type (Mori \& Prance 1990). Mori \& Lepsch-Cunha (1995) reported flowering of this species during the months of January and February, and noted that it occurred in the central and western regions of the Amazon. It is an endemic species to Brazil, occurring in the states of Amazonas, Acre, and Rondônia (Smith et al. 2010). The INPA herbarium has collections of this species from the states of Mato Grosso and Roraima.

Material examined: BRAZIL. AmAZonAs: Manaus, Tupé Sustainable Development Reserve, 31-VIII-2005, $R A$ Borges 43 (INPA); 11-X-2005, RA Borges 50 (INPA).

Additional material examined: BRAZIL. AmAzonAs: Manaus, Reserva Ducke, 6-I-1966, W Rodrigues \& Osmarino 7387 (INPA); Reserva Ducke, 27-II-1996, MAD Souza et al. 229 (INPA).

Lecythis Loefl., Iter Hispan. 176-189. 1758.

This genus is characterized by sub-canopy to emergent trees; small to large leaves (2.5-40 cm long), glabrous; flowers with zygomorphic androecium; with 6 sepals and 6 petals; hood variable, can be flat or flat and thick, with vestigial stamens turned inward without forming a spiral, or hood turned inward forming a single spiral; ovary generally 4-locular, with 2 to various ovules; fruit of the pyxidium type; seeds generally with basal aril.

The genus is neotropical with 27 described species, distributed from Nicaragua to the valleys of the Andes, the Pacific Coast of Ecuador and Colombia, throughout the Amazon region and the Guianas, and in the Brazilian Atlantic Forest. Only one species of this genus was encountered in the Tupé SDR.

10. Lecythis poiteaui O.Berg, in Mart., Fl. bras 14(1): 615. 1859.

Figures 93-103

Trees $23 \mathrm{~m}$ tall. Trunk and base cylindrical; outer bark brown, superficial vertical fissures, with lenticels; 
inner bark bright-yellow. Leaves with adaxial face shiny and abaxial face whitish and dull; petiole glabrous, flat-convex, 8-13 mm long; leaf blade elliptical, 11.5$17.5 \times 4.0-7.5 \mathrm{~cm}$, glabrous, coriaceous; base obtuse or rounded; margins crenulate; apex acuminate; venation brochidodromous; midrib prominent on the adaxial face and salient on the abaxial face. Inflorescence terminal, racemose, glabrous, 9-19 cm long; pedicel glabrous, 4-6 mm long. Flowers zygomorphic; calyx with 6 sepals, ovate, $8-12.5 \times 7.5-10.5 \mathrm{~mm}$, imbricate, green; petals 6 , ovate with revolute margins, $35 \times 22-25 \mathrm{~mm}$, imbricate, green; hood flat; stamen ring with more than
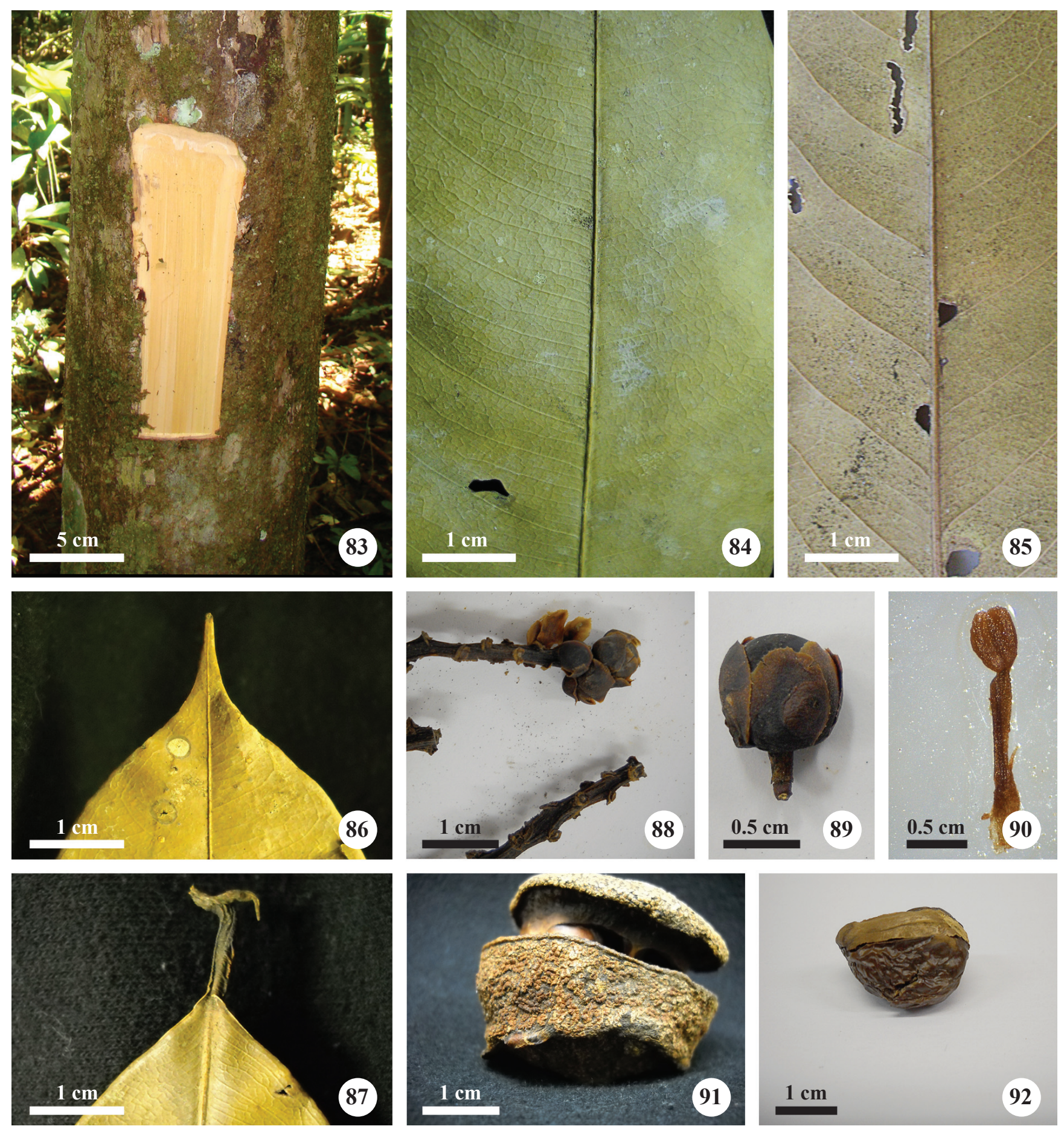

Figures 83-92. Eschweilera truncata. 83. Outer and inner bark. 84. Leaf with prominent midrib on adaxial surface. 85. Midrib salient on abaxial surface. 86. Leaf apex long-acuminate. 87. Base obtuse. 88. Angular rachis with buds. 89. Bud. 90. Stamen with straight filament. 91. Fruit subglobose. 92. Seed with fleshy lateral aril. 
1000 stamens, filaments clavate, 3-4 mm long, anthers rimose, 0.8-1 mm long; ovary inferior, 4-locular, 12-16 ovules per locule, placentation axial, stigma geniculate, $6 \mathrm{~mm}$ long, well differentiated from the cupule of the ovary. Fruit subglobose, $2-7 \times 6 \mathrm{~cm}$, calyx persistent in the mature fruit, operculum without columella. Seeds 4-6 per fruit, with fleshy aril in the basal region.

This species has the principal characteristics of a cylindrical trunk, inner bark bright-yellow; leaves with adaxial face shiny and margins crenulate, abaxial
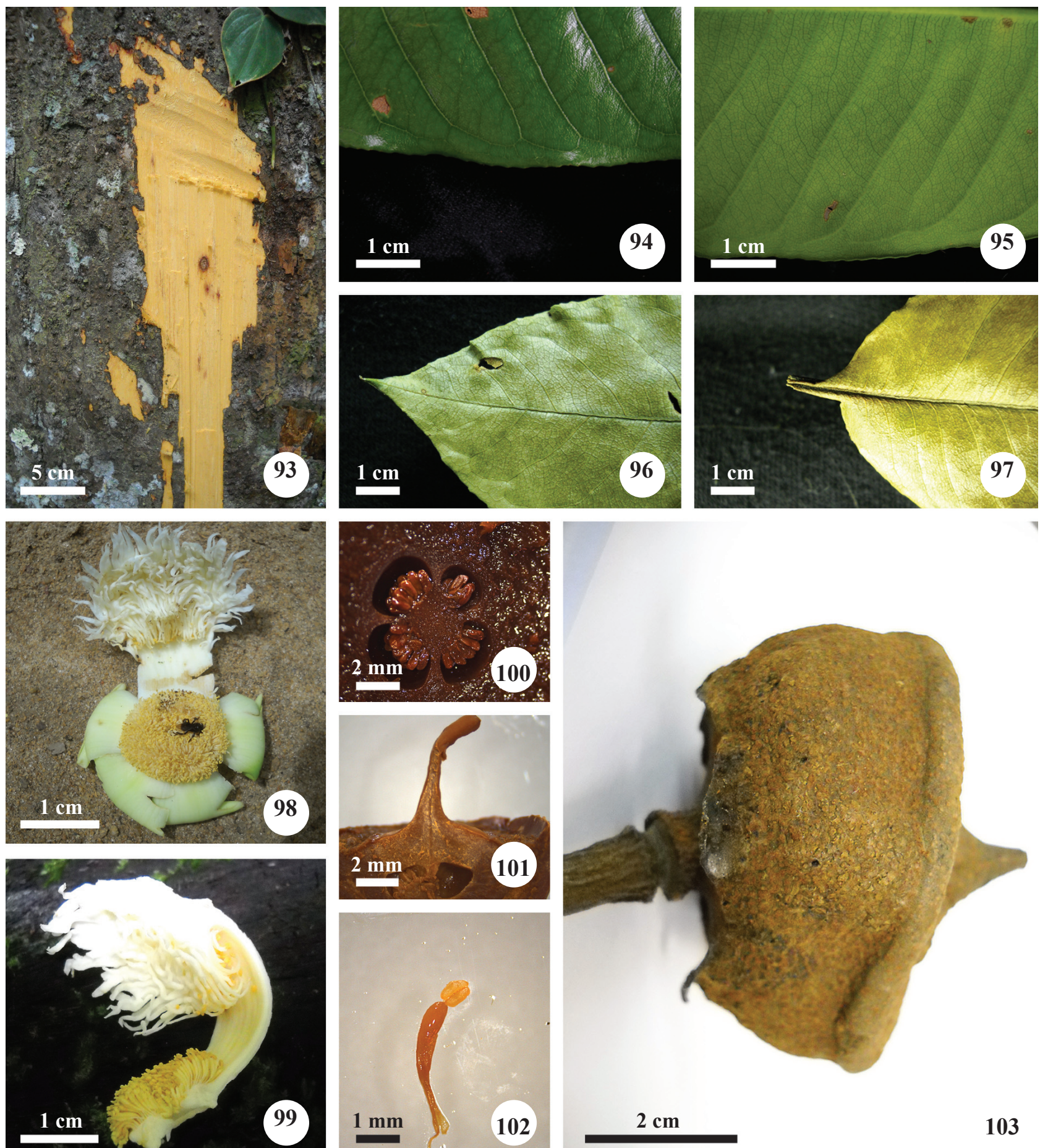

$\checkmark$
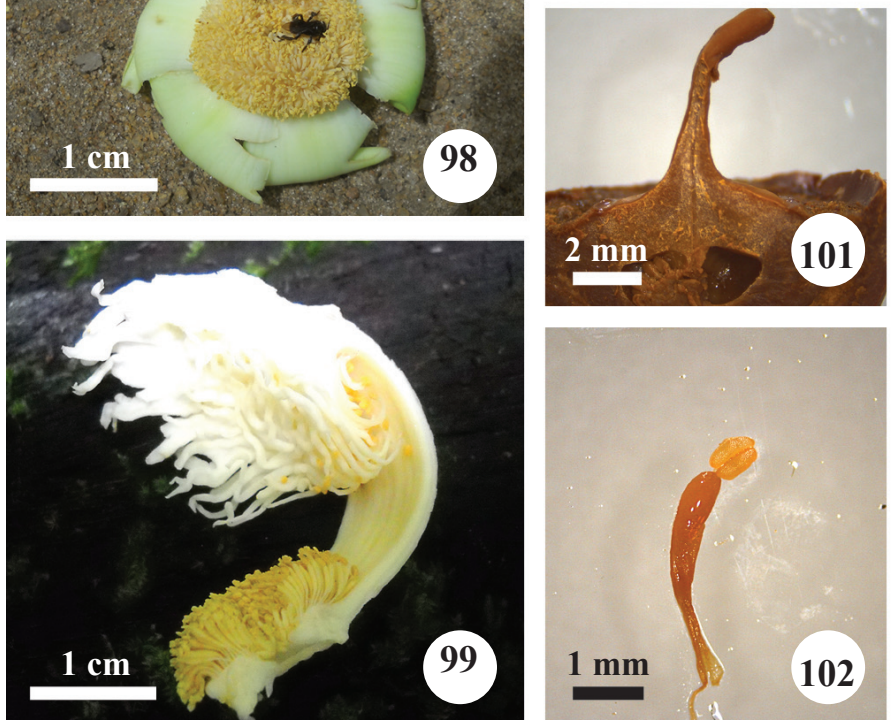

Figures 93-103. Lecythis poiteaui. 93. Outer and inner bark. 94. Leaf with shiny adaxial surface and crenulate margin. 95. Abaxial leaf surface. 96. Acuminate apex. 97. Base rounded, decurrent. 98. Flower in apical view. 99. Androecium in longitudinal section, showing the flat hood. 100. 4-locular ovary. 101. Style geniculate, well differentiated from cupule of the ovary. 102. Stamen with clavate filament. 103. Fruit subglobose. 
face with papilose cuticle; flowers with flat hood and green petals with revolute margins; fruit subglobose, seeds with basal aril. This aril is nutritious, attracting animals that disperse the seeds while consuming it (Mori \& Prance 1981). This type of attractive and nutritious fleshy aril (which is encountered in the genera Eschweilera and Lecythis) is typical of species whose seeds are dispersed by animals. According to Mori \& Lepsch-Cunha (1995) Lecythis poiteaui has inflorescences that are projected above the canopy, open at night, and have approximately 1000 stamens. Mori \& Prance (1990) noted that L. poiteaui is similar to L. barnebyi S.A.Mori and L. brancoensis (R.Knuth) S.A.Mori, as they share a number of diagnostic characters such as terminal inflorescences and a flat hood with anther-like appendices, and the stamens composing the stamen ring are numerous and densely united. Lecythis poiteaui and L. barnebyi are morphologically similar and are the only known neotropical species of Lecythidaceae that are pollinated by bats (Mori \& Lepsch-Cunha 1995). Some of the floral characteristics of this species, such as nocturnal flowers, inflorescence projected above the canopy, numerous stamens, the emission of a disagreeable odor by the flowers, and green revolute petals were used by Mori \& Prance (1990) to justify the creation of the section Poiteaui. This section comprises three species (L. poiteaui, $L$. barnebyi, and L. brancoensis) that have characteristics typical of chiropterophilous flowers. The most notable differences between L. poiteaui and L. barnebyi are smaller leaves with fewer pairs of lateral veins in $L$. poiteaui, with the abaxial region of the petals being pink or red in $L$. barnebyi (vs. green or white in $L$. poiteaui). Many small bees were observed visiting flowers that had fallen from the tree and were lying on the ground.

Lecythis poiteaui was collected with flowers in November and was encountered in the upland terra-firme forests in the Tupé SDR. Mori \& Lepsch-Cunha (1995) reported flowering in this species from July to September; Mori \& Prance (1990) noted the presence of flowers from October to March and fruits from April to June, and identified this species as typical of non-flooding forests. These same authors mentioned that this species could be encountered in Suriname, French Guiana, and in the Brazilian Amazon from Manaus to the mouth of the Amazon River in Pará State. The INPA herbarium has records of this species from Amapá State.

Material examined: BRAZIL. AmAzonAs: Manaus, Tupé Sustainable Development Reserve, 14-XI-2010, L Matta \& WR Brito 19 (INPA).
Complementary material examined: BRAZIL. Amazonas: Manaus, Reserva Ducke, camp road, 200 meters from the main road, 12-II-1969, O Pires 19 (INPA); Tarumã road, near Ponte Negra, 10-I-1967, GT Prance et al. 3923 (INPA); Rodovia Manaus Itacoatiara, trilha L-05, km 6,5, 14-III-2003, Castilho et al. s.n. (INPA); Rodovia Manaus - Itacoatiara, trilha L-04, km 5,5, 4-XII-2002, EC Pereira 260 (INPA).

Acknowledgments - The authors thank Fapeam for logistical and infrastructure support in the field by way of the projects PIPT and PINFRA; CNPq for awarding a Master's grant to the first author and for providing for the acquisition of the permanent equipment utilized in this study by way of the CT - Amazon project; the inhabitants of Julião's Community for their hospitality; the members of the Biotupé project for their help with the fieldwork; and the specialist in this plant family, Dr. Scott Mori, for his help and for confirming the identifications of the species studied.

\section{REFERENCES}

Anderberg AA, Rydin C, Källersjö M. 2002. Phylogenetic relationships in the order Ericales s.1.: analyses of molecular data from five genes from the plastid and mitochondrial genomes. American Journal of Botany 89:677-687.

APG (Angiosperm Phylogeny Group). 2009. An update of the Angiosperm Phylogeny Group classification for the orders and families of flowering plants: APG III. Botanical Journal of the Linnean Society 161:105-121.

Cavalcanti MJ, Santos-Silva EN. 2009. Free Delta: um sistema de software livre para o processamento de descrições taxonômicas. In Biotupé: meio físico, diversidade biológica e sociocultural do baixo Rio Negro, Amazônia Central. (EN Santos-Silva, VV Scudeller, eds.). Universidade Estadual do Amazonas - UEA Ltda., Manaus, v.2, p.89-95.

Ducke A. 1948. Árvores amazônicas e sua propagação. Boletim do Museu Paraense Emílio Goeldi 10:81-92.

Ellis B, Daly DC, Hickey LJ, Johnson KR, Mitchell JD, Peter W, Wing SL. 2009. Manual of leaf architecture. Cornell University Press, New York.

Hamaguchi JO. 2009. Estrutura e composição florística das espécies arbóreas e arbustivas de uma floresta de igapó no Lago Tupé, Manaus, AM. Dissertação de mestrado, Instituto Nacional de Pesquisas da Amazônia, Manaus.

Hopkins MJG, Mori SA. 1999. Lecythidaceae. In Flora da Reserva Ducke: guia de identificação das plantas vasculares de uma floresta de terra-firme na Amazônia Central (JELS Ribeiro, MJG Hopkins, A Vicentini, CA Sothers, MAS Costa, JM Brito, MAD Souza, LHP Martins, LG Lohmann, PACL Assunção, EC Pereira, CF Silva, MR Mesquita, LC Procópio, eds.). Instituto Nacional de Pesquisas da Amazônia, Manaus, p.273-287. 
Maués MM. 2002. Reproductive phenology and pollination of the Brazil nut tree (Bertholletia excelsa Humb. \& Bonpl., Lecythidaceae) in Eastern Amazonia. In Pollinating bees: the conservation link between agriculture and nature $(\mathrm{P}$ Kevan, VL Imperatriz Fonseca, eds.). Ministério do Meio Ambiente, Brasília, p.245-254.

Mori SA. 2004. Lecythidaceae. In Flowering plants of the Neotropics (N Smith, SA Mori, A Henderson, DW Stevenson, SV Heald, eds.). New York Botanical Garden Press, New York, p.207-209.

Mori SA. 2007. Lecythidaceae. In Manual de plantas de Costa Rica. Dicotiledóneas (Haloragaceae-Phytolaccaceae) (BE Hammel, MH Grayum, C Herrera, M Zamora, eds.). Missouri Botanical Garden Press, St. Louis, v.6, p.173-186.

Mori SA, Lepsch-Cunha N. 1995. The Lecythidaceae of a Central Amazonian moist forest. Memoirs of the New York Botanical Garden 75:1-55.

Mori SA, Prance GT. 1981. Relações entre a classificação genérica de Lecythidaceae do Novo Mundo e seus polinizadores e dispersadores. Revista Brasileira de Botânica 4:31-37.

Mori SA, Prance GT. 1990. Lecythidaceae - Part II. The zygomorphic-flowered New World genera (Couroupita, Corythophora, Bertholletia, Couratari, Eschweilera and Lecythis). Flora Neotropica Monographs 21, The New York Botanical Garden Press, New York., v.2.

Mori SA, Prance GT. 1993. 53. Lecythidaceae. In Flora of the Guianas, Series A: Phanerogams. Fascicle 12 (ARA Görts-Van Rijn, ed.). Koeltz Scientific Books, Koenigstein p.1-144.

Mori SA, Prance GT. 1999. Lecythidaceae. In Flora of the Venezuelan Guayana. Eriocaulaceae-Lentibulariaceae (PE Berry, K Yatskievych, BK Holst, eds.). Missouri Botanical Garden Press, St. Louis, v.5, p.750-779.

Mori SA, Boom BM, Prance GT, Black D, Zeeuw C, Mitchell JD, Cremers G, Boeke JD. 1987. The Lecythidaceae of a lowland neotropical forest: La Fumée Mountain, French Guiana. Memoirs of the New York Botanical Garden 44:1-190.
Mori SA, Tsou CH, Wu CC, Cronholm B, Anderberg AA. 2007. Evolution of Lecythidaceae with an emphasis on the circumscription of Neotropical genera: information from combined ndhF and trnL-F sequence data. American Journal of Botany 94:289-301.

Mori SA, Smith NP, Cornejo X, Prance GT. 18 March 2010 onward. Lecythidaceae pages. The New York Botanical Garden, New York. http://sweetgum.nybg.org/lp/index. php (accessed 2011 Oct 18).

Prance GT, Mori SA. 1978. Observations on the fruits and seeds of Neotropical Lecythidaceae. Brittonia 30: 21-33.

Prance GT, Mori SA. 1979. Lecythidaceae - Part I. The actinomorphic-flowered New World Lecythidaceae (Asteranthos, Gustavia, Grias, Allantoma, and Cariniana). Flora Neotropica Monographs 21:1-270.

Prance GT, Mori SA. 2004. Lecythidaceae. In The families and genera of vascular plants. VI. Flowering plants. Dicotyledons. Celastrales, Oxalidales, Rosales, Cornales, Ericales (K Kubitzki, ed.). Springer-Verlag, New York, p.221-232.

Radford AE, Dickison WC, Massey JR, Bell CR. 1974. Vascular plant systematics. Harper and Row, New York.

Scudeller VV, Souza AMG. 2009. Florística da mata de igapó na Amazônia Central. In Biotupé: meio físico, diversidade biológica e sociocultural do baixo Rio Negro, Amazônia Central. (EN Santos-Silva, VV Scudeller, eds.). Universidade Estadual do Amazonas - UEA Ltda., Manaus, v.2, p.97-108.

Scudeller VV, Ramos RA, Cruz MEG. 2009. Flora fanerogâmica da floresta de terra-firme na RDS Tupé. In Biotupé: meio físico, diversidade biológica e sociocultural do baixo Rio Negro, Amazônia Central. (EN Santos-Silva, VV Scudeller, eds.). Universidade Estadual do Amazonas - UEA Ltda., Manaus, v.2, p.109-120.

Smith NP, Mori SA, Prance GT. 2010. Lecythidaceae. In Lista de espécies da flora do Brasil. Jardim Botânico do Rio de Janeiro, Rio de Janeiro. http://floradobrasil.jbrj. gov.br/2010/FB000145 (accessed 2011 May 27). 